\title{
Global expression analysis of nucleotide binding site-leucine rich repeat-encoding and related genes in Arabidopsis Xiaoping Tan ${ }^{1}$, Blake C Meyers ${ }^{2}$, Alexander Kozik ${ }^{1}$, Marilyn AL West ${ }^{3}$, Michele Morgante ${ }^{4}$, Dina A St Clair ${ }^{3}$, Andrew F Bent ${ }^{5}$ and Richard W Michelmore*1,3
}

\begin{abstract}
Address: ${ }^{1}$ The Genome Center, University of California, Davis, California 95616, USA, ${ }^{2}$ Department of Plant and Soil Sciences, University of Delaware, Delaware Biotechnology Institute, 15 Innovation Way, Newark, Delaware 19711, USA, ${ }^{3}$ Department of Plant Sciences, University of California, Davis, California 95616, USA, ${ }^{4}$ Dipartimento di Scienze Agrarie ed Ambientali, Universitá degli Studi di Udine, Via delle Scienze 208, I-33100 Udine, Italy and ${ }^{5}$ Department of Plant Pathology, University of Wisconsin, Madison, Wisconsin 53706, USA

Email: Xiaoping Tan - xpitan@ucdavis.edu; Blake C Meyers - meyers@dbi.udel.edu; Alexander Kozik - akozik@atgc.org; Marilyn AL West - mlwest@ucdavis.edu; Michele Morgante - michele.morgante@uniud.it; Dina A St Clair - dastclair@ucdavis.edu; Andrew F Bent - afb@plantpath.wisc.edu; Richard W Michelmore* - rwmichelmore@ucdavis.edu

* Corresponding author
\end{abstract}

Published: 23 October 2007

BMC Plant Biology 2007, 7:56 doi:10.1 I86/147|-2229-7-56
Received: 23 May 2007

Accepted: 23 October 2007

This article is available from: http://www.biomedcentral.com/147/-2229/7/56

(c) 2007 Tan et al; licensee BioMed Central Ltd.

This is an Open Access article distributed under the terms of the Creative Commons Attribution License (http://creativecommons.org/licenses/by/2.0), which permits unrestricted use, distribution, and reproduction in any medium, provided the original work is properly cited.

\begin{abstract}
Background: Nucleotide binding site-leucine rich repeat (NBS-LRR)-encoding genes comprise the largest class of plant disease resistance genes. The 149 NBS-LRR-encoding genes and the 58 related genes that do not encode LRRs represent approximately $0.8 \%$ of all ORFs so far annotated in Arabidopsis ecotype Col-0. Despite their prevalence in the genome and functional importance, there was little information regarding expression of these genes.
\end{abstract}

Results: We analyzed the expression patterns of I 70 NBS-LRR-encoding and related genes in Arabidopsis Col-0 using multiple analytical approaches: expressed sequenced tag (EST) representation, massively parallel signature sequencing (MPSS), microarray analysis, rapid amplification of cDNA ends (RACE) PCR, and gene trap lines. Most of these genes were expressed at low levels with a variety of tissue specificities. Expression was detected by at least one approach for all but 10 of these genes. The expression of some but not the majority of NBS-LRR-encoding and related genes was affected by salicylic acid (SA) treatment; the response to SA varied among different accessions. An analysis of previously published microarray data indicated that ten NBS-LRR-encoding and related genes exhibited increased expression in wild-type Landsberg erecta (Ler) after flagellin treatment. Several of these ten genes also showed altered expression after $S A$ treatment, consistent with the regulation of $R$ gene expression during defense responses and overlap between the basal defense response and salicylic acid signaling pathways. Enhancer trap analysis indicated that neither jasmonic acid nor benzothiadiazole (BTH), a salicylic acid analog, induced detectable expression of the five NBS-LRR-encoding genes and one TIR-NBS-encoding gene tested; however, BTH did induce detectable expression of the other TIR-NBS-encoding gene analyzed. Evidence for alternative mRNA polyadenylation sites was observed for many of the tested genes. Evidence for alternative splicing was found for at least 12 genes, II of which encode TIR-NBS-LRR proteins. There was no obvious correlation between expression pattern, phylogenetic relationship or genomic location of the NBS-LRR-encoding and related genes studied.

Conclusion: Transcripts of many NBS-LRR-encoding and related genes were defined. Most were present at low levels and exhibited tissue-specific expression patterns. Expression data are consistent with most Arabidopsis NBS-LRRencoding and related genes functioning in plant defense responses but do not preclude other biological roles. 


\section{Background}

Over 40 plant resistance $(R)$ genes that are effective against diverse pathogens and pests, including bacteria, fungi, viruses, nematodes, and insects, have been cloned from both monocot and dicot plant species. These $R$ genes can be divided into at least five classes based on the structure of their encoded proteins [1-4]. Genes encoding nucleotide binding site-leucine rich repeat (NBS-LRR) proteins are the most prevalent and can be divided into two major groups based on the encoded N-terminal domains and differences in the NBS domain, as well as several subgroups [5-8]. One major group predominantly encodes a coiled coil domain at the N-terminus (CC-NBSLRR or "CNL"; e.g. RPS2 and RPM1), whereas the other group has an N-terminal domain with similarity to the cytoplasmic domain of Drosophila and human Toll-like receptor (Toll-interleukin-1 receptor-like (TIR) domain; TIR-NBS-LRR or "TNL"; e.g. L6, N and RPP5). In the Arabidopsis Col-0 genome 149 NBS-LRR-encoding genes (55 CC-NBS-LRR and 94 TIR-NBS-LRR) and an additional 58 related genes that do not encode LRRs have been identified $[7,9]$. Based on phylogenetic analysis, protein motif comparisons, and intron positions, four CNL subgroups, eight TNL subgroups, and a pair of divergent "NL" proteins have been identified in Arabidopsis $[7,10]$. These NBS-LRR-encoding genes are distributed as single genes, clusters, and superclusters in plant genomes $[5,7,10,11]$.

Disease resistance is the predominant function so far demonstrated for plant NBS-LRR-encoding genes [2]. How NBS-LRR proteins function in disease resistance is still under investigation [8]. In addition to directly detecting pathogen ligands, $\mathrm{R}$ proteins may also monitor ('guard') the status of the targets of pathogen virulence effectors, or the cellular consequences of the actions of these proteins [2,12-16]. The LRR domains may be involved in protein-protein interactions and at least partly determine resistance specificity [17-27]. Polymorphism in the TIR region has also been shown to affect resistance specificity $[23,28]$. In addition to their role in determining the recognition specificity, the LRR domains may also participate in defense signaling through both intra- and intermolecular interactions [27,29-32]. NBS regions contain several conserved motifs and are homologous to the NBARC (nucleotide binding domain shared by Apaf-1, some $R$ genes and Ced-4) domain of some eukaryotic cell death effectors such as Apaf-1 and Ced-4 [33]. The NBS domains of two NBS-LRR proteins, tomato I2 and Mi-1, have been demonstrated to be able to bind and hydrolyze ATP [34] and the ATP binding form is the active configuration of the I2 protein [35], suggesting that the NBS domain functions as a molecular switch in signal transduction eliciting the defense response. The role of CC-NBS and TIR-NBS proteins that lack an LRR domain is unknown but they may function as adaptor proteins similar to Myd88 in mammalian systems [9].

Over 14 NBS-LRR-encoding genes that confer resistance against bacterial, Oomycete, fungal, or viral pathogens have been isolated from Arabidopsis (Table 1). The majority of the subgroups of NBS-LRR-encoding genes contain at least one known $R$ gene or its closest homolog in the Col-0 genome, suggesting that the majority of NBSLRR-encoding genes could be involved in resistance. However, some of the smaller and more divergent subgroups do not contain a known resistance gene and there is limited evidence for the involvement of NBS-LRR proteins in other aspects of plant biology, such as plant development. A T-DNA insertion mutant of an Arabidopsis TIR-NBS-LRR-encoding gene has altered shade avoidance as well as disease susceptibility [36]. The adenylyl cyclase $(A C)$ gene cloned from maize pollen plays a role in pollen-polarized growth, for example, and has sequence similarity to NBS-LRR-encoding genes [37]. The tomato I-2 gene (CNL type) is expressed at the site of lateral root formation suggesting that it may have functions in addition to pathogen recognition [38]. The other four protein classes that include $R$ gene products also contain proteins that participate in other processes, such as two receptorlike kinases, CLAVATA1 and brassinosteroid insensitive 1 (BRI1), that are involved in development and hormone reception, respectively, and another receptor-like protein, CLAVATA 2, which functions in plant development [3942]. Analysis of the expression patterns of NBS-LRRencoding genes in Arabidopsis may provide clues as to their functions.

Although an increasing number of $R$ genes are being cloned, little is known about the regulation of plant $R$ gene expression. RNA gel-blot analyses have detected low levels of transcripts for most cloned $R$ genes in unchallenged plants $[1,38,43-48]$. However, the expression of few $R$ genes has been investigated in detail. Seven TIRNBS-LRR-encoding $R$ genes ( L6, Rpp5, N, M, RPS4, RAC1, and $B s 4$ ) have been shown to encode two or more transcripts [46,49-54]; however, the role of alternative splicing in disease resistance is unknown. The alternative transcripts of tobacco $N$ gene and Arabidopsis RPS4 are known to be important for the defense responses mediated by these two $R$ genes [50,52]. Rare alternative splicing has been found for CC-NBS-LRR-encoding $R$ genes. In common bean, the alternative transcripts were identified for CC-NBS-LRR-encoding gene JA1tr and the alternative splicing is not regulated by pathogen infection [55]. Induction of resistance gene expression by pathogen infection has only been reported for a very small number of $R$ genes, such as sugar beet $H s 1^{\text {pro-1 }}$, barley Mla, rice Xa1, and Xa27 [56-59]. The induction of a recently cloned rice Xa27 gene, encoding a protein with no homology with 
Table I: Fourteen NBS-LRR-encoding disease resistance genes cloned from Arabidopsis

\begin{tabular}{|c|c|c|c|c|c|c|}
\hline Gene & $\begin{array}{c}\text { Gene or closest } \\
\text { homolog in } \\
\text { Col-0 }\end{array}$ & Class & Pathway & Pathogen & Avr gene & Reference \\
\hline RPMI & At3g07040 & $\mathrm{CNL}$ & NDRI & Pseudomonas syringae & avrRpml, avrB & {$[43,117-120]$} \\
\hline RPS2 & At4g26090 & $\mathrm{CNL}$ & NDRI & Pseudomonas syringae & avrRpt2 & {$[119,121-124]$} \\
\hline RPS4 & At5g45250 & TNL & EDSI & Pseudomonas syringae & avrRps4 & {$[100,125,126]$} \\
\hline RPS5 & At $|g| 2220$ & $\mathrm{CNL}$ & NDRI & Pseudomonas syringae & avrPphB & {$[29,119,127,128]$} \\
\hline RPPI & At3g44670 & TNL & EDSI & Hyaloperonospora parasitica & $A T R / N d W s B$ & {$[19,120,129]$} \\
\hline RPP4 & At4gl6860 & TNL & $\begin{array}{l}\text { EDSI (partial NDRI in } \\
\text { cotyledon) }\end{array}$ & Hyaloperonospora parasitica & & {$[119,126,130]$} \\
\hline RPP5 & At4gl6950 & $\mathrm{TNL}$ & EDSI & Hyaloperonospora parasitica & & {$[46,126]$} \\
\hline RPP8/HRT/RCYI & At5g43470 & $\mathrm{CNL}$ & Non-EDSI, Non-NDRI & $\begin{array}{l}\text { Hyaloperonospora parasitica; } \\
\text { turnip crinkle virus; } \\
\text { cucumber mosaic virus }\end{array}$ & & {$[20,126,131-133]$} \\
\hline RPPI3 & At3g46530 & $\mathrm{CNL}$ & Non-EDSI, Non-NDRI & Hyaloperonospora parasitica & ATR/3 & {$[134-136]$} \\
\hline$R R S I-R$ & At5g45260 & TNLW & Partially NDR I & Ralstonia solanacearum & popP2 & {$[137,138]$} \\
\hline$R P P 2 A$ and $R P P 2 B$ & $\begin{array}{l}\text { At4g19500 } \\
\text { At4g19510 }\end{array}$ & TNTNL TNL & & Hyaloperonospora parasitica & & [139] \\
\hline RACI & Atlg31540 & TNL & EDSI & Albugo candida & & [53] \\
\hline$A D R I$ & Atlg33560 & $\mathrm{CNL}$ & & $\begin{array}{l}\text { Hyaloperonospora parasitica } \\
\text { and Erysiphe cichoracearum }\end{array}$ & & {$[140]$} \\
\hline RLMI & $\begin{array}{l}\text { Atlg64070 and } \\
\text { Atlg63880 }\end{array}$ & TNL & & Leptosphaeria maculans & & {$[14 \mid]$} \\
\hline
\end{tabular}

other R proteins, at the site of pathogen infection is correlated with resistance [59]. The expression of some NBSLRR-encoding $R$ genes have been shown be affected by factors other than pathogen infection, such as tissue type, developmental stage, or environmental conditions [38,60-62].

The methods for analysis of gene expression have advanced from single-gene approaches to a variety of global transcript profiling technologies $[63,64]$. Large scale expressed sequence tag (EST) sequencing [65] and serial analysis of gene expression (SAGE, [66]) allow quantitative evaluation of gene expression but are less informative than massively parallel signature sequencing (MPSS; $[67,68])$. MPSS generates millions of tags proximal to the 3 ' ends of transcripts in a stoichiometric manner; therefore the relative abundance of each transcript can be assessed in each sample and rare transcripts and previously unidentified genes can be detected. It is, however, costly and few samples can be analyzed. Microarrays allow an intermediate number of samples to be analyzed but require a priori knowledge of the genes expressed unless tiling arrays are used $[69,70]$. Current challenges in using microarray analysis include application of appropriate statistical approaches to identify significant changes in expression and making informative comparisons across diverse microarray datasets as well as integrating the microarray data with expression information derived from other approaches $[71,72]$.
In this paper, we describe multiple genomic approaches to characterize the expression of NBS-LRR-encoding and related genes in Arabidopsis. These approaches included representation in EST libraries, MPSS, microarray experiments, gene trap lines and RACE-PCR. The transcript structure was defined for over 80 genes. We determined the level, tissue specificity and possible inducibility of expression for $\sim 170$ NBS-LRR-encoding and related genes. Most of the NBS-LRR-encoding and related genes investigated were expressed at low levels and with variable tissue specificities. As previously observed for known $R$ genes, expression of these genes was induced during the plant defense response in only a minority of the cases examined. This study provides the foundation for further functional analysis of individual genes.

\section{Results}

Representation in Expressed Sequence Tag (EST) libraries We examined the frequency with which NBS-LRR-encoding transcripts were present in EST collections at several times during our study. In April 2002, a total of 181,406 Arabidopsis sequences from the NCBI EST database were searched for similarity to the spliced genomic ORFs and genomic sequences of 170 NBS-LRR-encoding and related genes. ESTs were detected for about half (98) of these 170 genes; most genes (81) had five or less representatives per gene. At these low frequencies other expressed NBS-LRRencoding and related genes could have gone undetected in this depth of EST sampling. Therefore more efficient and sensitive methods were used to analyze the expression of NBS-LRR-encoding and related genes. When the 
same analysis was repeated in July 2006, 622,792 Arabidopsis EST sequences were searched for similarity to 172 NBS-LRR-encoding and related genes. ESTs were detected for only about two thirds (120) of the 172 genes analyzed. Most of these (94) still had ten or fewer representatives per gene (Table 2; detailed information in additional file 1 and online database [73]).

\section{Massively Parallel Signature Sequencing (MPSS) analysis} The expression of 170 NBS-LRR-encoding and related genes was then determined by utilizing the DuPont MPSS database for Arabidopsis and the public Arabidopsis MPSS database ([74-77]). On average, there were approximately one million tags in each of the 22 DuPont libraries (Table 3 ) and about two and half million tags in each of the seventeen libraries generated by Meyers et al. (Table 4 ). These tags represent all the transcripts in a given sample and the frequency of each tag is correlated to the expression level of each represented gene.

Most of the 170 NBS-LRR-encoding and related genes were detected in at least one library and at low levels ( 1 to 991 adjusted parts per million (adjPPM) or transcripts per million (TPM) compared to reference genes such as EF-1 $\alpha$ (769 to 4061 adjPPM) and ACT-2 (6-2925 adjPPM) (reference genes used in [9]). The most highly expressed NBSLRR-encoding or related gene was At3g04210 at a level of 991 TPM in the library made from leaves 52 hours after treatment with salicylic acid (S52). The second most highly expressed gene (683 TPM) was At1g72900 in the library made from callus (CAS). The gene with highest expression in untreated Arabidopsis tissues was
At3g04210, which was expressed at 322 TPM in a library made from leaf (LES). Other genes were expressed at much lower levels than these two genes. About half of the genes (73) were expressed at very low levels of less than 32 adjPPM or TPM. Expression of only 11 genes was not detected in any of the 37 MPSS libraries. The genes exhibiting higher levels of expression in the MPSS analysis, for example At4g33300 and At3g50950, were also well represented in the EST dataset. Expression of 17 of the 21 predicted or potential pseudogenes in Col-0 genome [7] was detected in at least one MPSS libraries generated from tissue of Col-0.

The total number of NBS-LRR-encoding and related genes expressed varied widely between MPSS libraries from 101 detected in the Col-0 leaf library (LEF), to 15 detected in the library made from Col-0 late stage developing seeds (Ase $2 \mathrm{~lm}-\mathrm{la}$ ). On average, each gene was present in only 15 of the 39 libraries (Additional file 1). The four most prevalent genes, At1g61190, At1g61300, At1g59124, and At3g07040, which all encode CC-NBS-LRR proteins, were detected in 37 out of 39 libraries studied.

Most NBS-LRR-encoding and related genes exhibited different levels of expression in different tissues, at different developmental stages or in different genotypes of Arabidopsis (Additional file 1). Forty NBS-LRR-encoding and related genes were expressed at a higher level in callus than in any other tissues examined in the public Arabidopsis MPSS database. Some genes were preferentially expressed in aerial plant parts (e.g. At5g44870, 58 TPM in leaf and 2 TPM in root), while others were root-specific

Table 2: Summary of EST, RACE, MPSS, and microarray expression analyses of NBS-LRR-encoding and related genes

\begin{tabular}{|c|c|c|c|c|c|c|c|c|c|}
\hline $\begin{array}{l}\text { Predicted Protein } \\
\text { Domains a }\end{array}$ & Code & $\begin{array}{c}\text { \# based on } \\
\text { prior } \\
\text { annotation }\end{array}$ & $\begin{array}{l}\text { \# based on } \\
\text { full manual } \\
\text { annotation }\end{array}$ & $\begin{array}{c}\text { ESTs (\# } \\
\text { expressed/ } \\
\text { \# studied) } \\
2002\end{array}$ & $\begin{array}{c}\text { ESTs (\# } \\
\text { expressed/ } \\
\text { \#studied) } \\
2006\end{array}$ & $\begin{array}{c}\text { RACE (\# } \\
\text { expressed/ } \\
\text { \# studied) }\end{array}$ & $\begin{array}{l}\text { MPSS (\# } \\
\text { expressed/ } \\
\text { \# studied) }\end{array}$ & $\begin{array}{c}\text { Microarray } \\
\text { (\#P or M/\# } \\
\text { studied)c }\end{array}$ & $\begin{array}{l}\text { \# detected } \\
\text { by both } \\
\text { MPSS and } \\
\text { microarray }\end{array}$ \\
\hline CC-NBS-LRR & $\mathrm{CNL}$ & 48 & 51 & $28 / 49$ & $36 / 51$ & $26 / 35$ & $46 / 49$ & $32 / 47$ & 31 \\
\hline $\mathrm{NBS}_{\mathrm{CC}}-\mathrm{LRR}$ & $\mathrm{NL}$ & 2 & 4 & $2 / 4$ & $3 / 4$ & $1 / 1$ & $3 / 4$ & $2 / 3$ & 2 \\
\hline TIR-NBS-LRR & TNL & 82 & 83 & $46 / 83$ & $56 / 83$ & $38 / 50$ & $79 / 83$ & $50 / 80$ & 50 \\
\hline $\mathrm{NBS}_{\mathrm{TIR}}-\mathrm{LRR}$ & $\mathrm{NL}$ & 2 & 2 & $0 / 2$ & $0 / 2$ & $0 / 1$ & $\mathrm{I} / 2$ & $0 / 2$ & 0 \\
\hline TIR-NBS-LRR-X & TNLX & 5 & 5 & $3 / 5$ & $4 / 5$ & $4 / 5$ & $5 / 5$ & $3 / 5$ & 3 \\
\hline TIR-NBS-TIR-NBS-LRR & TNTNL & 2 & 2 & $2 / 2$ & $2 / 2$ & $2 / 2$ & $2 / 2$ & $1 / 2$ & I \\
\hline TIR-TIR-NBS-LRR & TTNL & 0 & 2 & $2 / 2$ & $2 / 2$ & $2 / 2$ & $2 / 2$ & $2 / 2$ & 2 \\
\hline Total with LRRs & & $14 \mid$ & 149 & & & & & & \\
\hline TIR-NBS & $\mathrm{TN}$ & 14 & 21 & $9 / 15$ & $10 / 15$ & $5 / 9$ & $13 / 15$ & $10 / 15$ & 10 \\
\hline TIR-X & $\mathrm{TX}$ & 23 & 30 & & & & & & \\
\hline X-TIR-NBS-X & XTNX & 0 & 2 & $2 / 2$ & $2 / 2$ & & $2 / 2$ & $\mathrm{I} / 2$ & 1 \\
\hline CC-NBS & $\mathrm{CN}$ & 4 & 4 & $3 / 4$ & $3 / 4$ & $2 / 2$ & $4 / 4$ & $1 / 2$ & 1 \\
\hline CC-NBS-X & CNX & I & I & $\mathrm{I} / \mathrm{I}$ & I/I & $\mathrm{I} / \mathrm{I}$ & $1 / 1$ & I/I & I \\
\hline $\mathrm{CC}$ (related to $\mathrm{CNL}$ ) & $\mathrm{C}$ & 0 & I & & & & & & \\
\hline $\mathrm{NBS}_{\mathrm{CC}}$ & $N$ & 1 & 1 & $0 / 1$ & $1 / 1$ & $0 / 1$ & $1 / 1$ & $1 / 1$ & 1 \\
\hline Total without LRRs & & 43 & 58 & & & & & & \\
\hline Total & & & 207 & $98 / 170$ & $120 / 172$ & $81 / 109$ & $159 / 170$ & $104 / 162$ & 103 \\
\hline
\end{tabular}

a "CC" and "TIR" subscript indicates motifs predictive of a CC or TIR domain N-terminal to the NBS. The first four columns are from [7].

b NBS-LRR-encoding and related genes for which RACE-PCR products were detected for either 5' or 3'end, or both.

c Number called as present $(P)$ or marginal $(M)$ in one of the three control Col-0 samples collected 4 hours post treatment with $0.02 \%$ silwet (experiment

described in [79]; additional file I). ATHI array was used for transcript profiling. 
Table 3: MPSS libraries of Arabidopsis thaliana from Dupont MPSS databases

\begin{tabular}{|c|c|c|c|c|c|}
\hline Library & Code & Ecotype & Tissue & Description & \# signatures \\
\hline Ale IIm.I & $\mathrm{a}$ & Columbia & Leaf & Early and late leaves & 391295 \\
\hline Afl2lm.I & $b$ & Columbia & Flower - shoot & Flower and shoot meristems & 1997189 \\
\hline Arollm & c & Columbia & Root & Roots & 1531770 \\
\hline Ase2lm-ea & $d$ & Columbia & Seed & Early stage developing seeds & 1726426 \\
\hline Ase2lm-la & $\mathrm{e}$ & Columbia & Seed & Late stage developing seeds & 287779 \\
\hline Asellm & $f$ & Columbia & Seed & Germinating seeds & II 27420 \\
\hline Asegllm & $g$ & Columbia & Seed & gl2 mutant seed, 7 DAF & 1572064 \\
\hline Asd $2|\mathrm{~m}-\mathrm{t}| \mathrm{I} . \mathrm{I}$ & $\mathrm{h}$ & Columbia & Seedling & Top part of seedlings grown without sucrose & 1863086 \\
\hline Asd $21 \mathrm{~m}-\mathrm{t} 2 . \mathrm{I}$ & $\mathrm{i}$ & Columbia & Seedling & Top part of seedlings grown with sucrose & 1793820 \\
\hline Asd2lm-bl.I & j & Columbia & Seedling & Bottom part of seedlings grown without sucrose & 870914 \\
\hline Asd2lm-b2.I & $\mathrm{k}$ & Columbia & Seedling & Bottom part of seedlings grown with sucrose & 897853 \\
\hline AsdlIIrm.I & I & Columbia & Seedling & Stage I seedlings & II 52083 \\
\hline Ack Ilm-ctrGVG.I & $\mathrm{m}$ & Landsberg & Seedling & IPT plants untreated & 1893424 \\
\hline Ackllm-tr6.I & $\mathrm{n}$ & Landsberg & Seedling & IPT plants treated with DEX, 6hrs & 1639214 \\
\hline Ack IIm-tr24.I & o & Landsberg & Seedling & IPT plants treated with DEX, 24 hrs & 1783294 \\
\hline Abawt-ctr & $\mathrm{P}$ & Landsberg & Seedling & Wildtype plants, uninduced & 1477653 \\
\hline Abawt-tr & $q$ & Landsberg & Seedling & Wildtype plants, ABA induced & 1266435 \\
\hline Aabil-ctr & $r$ & Landsberg & Seedling & abil plants, uninduced, 3 and 5 hrs & 1656984 \\
\hline Aabil-tr & $s$ & Landsberg & Seedling & abil plants, ABA induced, 3 and 5 hrs & 1241725 \\
\hline Afl2lm.test & $\mathrm{t}$ & Columbia & Flower - shoot & Flower and shoot meristem & \\
\hline Ase2lm-ea.test & $\mathrm{u}$ & Columbia & Seed & Developing seeds, early stage & \\
\hline Ase7lm-WT & v & Columbia & Seed & Seed wt, 7 DAF & \\
\hline
\end{tabular}

(e.g. At5g45210, 28 TPM in roots, 0 PPM in leaves and other tissues). Some genes were expressed primarily in flowers (e.g. At1g63740, 52 TPM in flower, 17 TPM in silique, and less than 5 TPM in root, leaf and callus). Some were induced in response to a chemical or hormone (e.g. At1g72850, 12 adjPPM vs 3 adjPPM in the abscisic acid (ABA) induced Landsberg erecta (Ler) plants vs uninduced plants, respectively). This range of expression patterns suggests that NBS-LRR-encoding and related genes may have a variety of functions.

Visual inspection revealed no obvious correlation between the encoded protein structures (CC-NBS $(\mathrm{CN})$, CC-NBS-LRR (CNL), TIR-NBS (TN) or TIR-NBS-LRR (TNL)) of the genes studied and their expression patterns. Each group contained genes with different expression levels and tissue specificities. Within the four CNL subgroups

Table 4: MPSS libraries of Arabidopsis thaliana from public MPSS databases

\begin{tabular}{|c|c|c|c|c|c|}
\hline Library & Code $^{a}$ & Ecotype & Tissue & Description & \# signatures \\
\hline CAF & 1 & Columbia & Callus & Callus - actively growing & 1959539 \\
\hline INF & 2 & Columbia & Inflorescence & Inflorescence - mixed stage, immature buds & 1774306 \\
\hline LEF & 3 & Columbia & Leaf & Leaves - 2 I day, untreated & 2884598 \\
\hline ROF & 4 & Columbia & Root & Root -21 day, untreated & 3642632 \\
\hline SIF & 5 & Columbia & Silique & Silique -24 to $48 \mathrm{hr}$ post-fertilization & 2012859 \\
\hline API & 6 & Columbia & Inflorescence & ap I-10 inflorescence - mixed stage, immature buds & 2964724 \\
\hline AP3 & 7 & Columbia & Inflorescence & ap3-6 inflorescence - mixed stage, immature buds & 2435965 \\
\hline AGM & 8 & Columbia & Inflorescence & agamous inflorescence - mixed stage, immature buds & 2575670 \\
\hline INS & 9 & Columbia & Inflorescence & Inflorescence - mixed stage, immature buds & 2890894 \\
\hline ROS & 10 & Columbia & Root & Root -21 day, untreated & 2458436 \\
\hline SAP & 11 & Columbia & Inflorescence & sup/ap I inflorescence - mixed stage, immature buds & 2310350 \\
\hline S04 & 12 & Columbia & Leaf & Leaves, $4 \mathrm{hr}$ post SA treatment & 3006975 \\
\hline S52 & 13 & Columbia & Leaf & Leaves, $52 \mathrm{hr}$ post SA treatment & 2964840 \\
\hline LES & 14 & Columbia & Leaf & Leaves $-2 I$ day, untreated & 3109385 \\
\hline GSE & 15 & Columbia & Seedling & Germinating seedlings & 2550655 \\
\hline CAS & 16 & Columbia & Callus & Callus - actively growing & 1919458 \\
\hline SIS & 17 & Columbia & Silique & Silique - 24 to $48 \mathrm{hr}$ post-fertilization & 2349283 \\
\hline
\end{tabular}

aLibraries I to 5 were made using the classic MPSS protocol; all subsequent libraries were made using signature MPSS [75, 76]. 
and the eight TNL subgroups of NBS-LRR-encoding genes identified by Meyers et al. [7], a wide variety of gene expression patterns were observed (Additional file 1). Consequently, no correlation was detected between gene expression pattern and position on the phylogenetic tree. There was also no obvious correlation between chromosomal location and expression pattern (Additional file 1).

One hundred and twenty NBS-LRR-encoding or related genes (two divergent NLs, 32 CNLs, two CNs, one NL (CC type), one NBS (CC type), 63 TNLs, five TNLX, two TNTNL, two TTNL, one NL (TIR type), two XTNX, and seven TNs) studied were represented by more than one MPSS tag (Additional file 1). Multiple tags can be detected for one gene when alternative splicing results in different stop codons and polyadenylation sites or when the polyadenylation site varies either side of a Sau3A site [9]. A total of 72 genes showed possible alternative polyadenylation. Twelve of these genes showed possible alternative splicing because some of the tags detected were located at splice sites or within introns; 11 out of these 12 genes were of TNLs rather than CNLs, consistent with the multiple introns in TNL-encoding genes and a paucity of introns in CNL-encoding genes. Alternative splicing was confirmed by RACE-PCR and subsequent sequencing for four of these genes: At1g63750, At4g16860 (RPP4 homolog in Col-0), At4g16950 (RPP5 homolog in Col-0), and At5g46270. The failure to detect alternative transcripts for the other eight genes may have been due to tissue specificity or low abundance of the alternatively spliced transcripts. For other genes with multiple tags detected, some were due to shifts in the polyadenylation site and some were due to the tags representing several members of a gene family.

\section{Microarray analysis}

To examine expression under a different range of conditions than those from which the MPSS libraries had been made, the expression of NBS-LRR-encoding and related genes was also analyzed using data from Affymetrix microarrays that were generated as components of two larger studies $[78,79]$. Both of these experiments utilized the whole genome array (ATH1; Affymetrix), which contained 152 probe sets representing 162 NBS-LRR-encoding and related genes which were located on the phylogenetic tree generated by Meyers et al. [7], including 13 known resistance genes (RPP8 is not represented on this array) or their homologs in Col-0.

In one experiment, changes of expression of NBS-LRRencoding and related genes in response to application of $0.3 \mathrm{mM}$ salicylic acid (SA) were analyzed in seven Arabidopsis accessions (Col-0, Cvi-1, Est, Kin-0, Mt-0, Tsu-1, and Van-0) as part of a study to identify expression level polymorphisms as described in [79] and ELP website [80].
Re-analysis of this data revealed that approximately twothirds of the NBS-LRR-encoding and related genes were expressed above the detection threshold in the control Col-0 sample (in at least one of the three replicates collected 4 hours post treatment with $0.02 \%$ silwet). The expression of nine genes, At1g57630, At1g59124, At1g72900, At1g72910, At3g04210, At3g50950, At4g16950, At4g33300, and At5g45510 in at least one of the three control Col-0 samples was higher than the average of present signal in the corresponding control Col-0 sample. Based on their expression levels in the control samples, most of the 162 NBS-LRR-encoding and related genes (138 probe sets out of 152 probe sets) exhibit significant differences in their expression levels between at least one pair of Arabidopsis accessions, suggesting the natural variation in expression of NBS-LRR-encoding genes between different accessions.

The expression levels of the majority of NBS-LRR-encoding and related genes were not significantly altered by the SA treatment compared to control samples harvested at the same timepoints; however, the expression of 15 genes (three CNLs (At3g14470, At5g04720, and At5g66900), one CN (At5g45490), one CNX (At5g66630), seven TNLs (At1g17600, At3g44630, At4g12010, At4g16860 (RPP4 homolog), At5g36930, At5g41740, and At5g46520), two TNs (At1g66090 and At1g72900), and one divergent NL (At5g45510)) was significantly induced in Col-0 plants 4 hours after SA treatment (Additional files 1 and 2). In addition, the expression of four NBS-LRR-encoding and related genes (two TNLs (At3g44400 and At4g36150), one TN (At3g04210), and one CNL (At3g50950)) was down-regulated in Col-0 plants 28 hours after SA treatment. These four genes also showed increases in their expression 4 hours after SA treatment though not to a statistically significant extent.

The expression of different NBS-LRR-encoding and related genes was affected at different time points after SA treatment in the various Arabidopsis accessions (Additional file 2). A total of 33 probe sets exhibited differential expression in response to SA treatment in at least one Arabidopsis accession. Some NBS-LRR-encoding genes exhibited similar responses to SA treatment across different accessions though some do not. For example, the expression of one CNL-encoding gene, At1g12280, was downregulated both in Est 4 hours after SA treatment and in Van-0 28 hours after SA treatment. One CNL gene, At4g14610, showed elevated expression 4 hours after SA treatment in Kin-0 and Tsu-1. One CNL gene, At5g66900, showed elevated expression in five Arabidopsis accessions, Col-0, Kin-0, Mt-0, Tsu- 1 , and Van-0, 4 hours after SA treatment but down-regulated expression 28 hours after SA treatment in Van-0 only. 
In order to compare the SA responses to changes of expression during the basal defense response, we reanalyzed the data set on the response to flagellin generated by Zipfel et al. [78] using the same procedures as used above. In this analysis, less than half of the NBS-LRR-encoding and related genes (69) were expressed above the detection threshold in at least one of the two control wild-type Landsberg erecta (Ler) samples. The expression of ten NBS-LRR-encoding and related genes (five CNLs (At3g07040 (RPM1), At3g50950, At4g26090 (RPS2), At4g33300, and At5g04720), three TNLs (At1g56510, At1g56540, and At5g22690), and two TNs (At1g72900 and At1g72940)) was induced by flagellin treatment in wild-type Ler. Interestingly, out of these ten NBS-LRRencoding and related genes, one gene, At1g72900, was also induced in Col-0 and Van-0 4 hours after SA treatment; one gene, At5g04720, was also induced in Col-0 and Mt-0 4 hours after SA treatment; two genes, At4g33300 and At1g56510, were also induced in Mt-0 4 hours after SA treatment; and one gene, At3g50950, exhibited down-regulated expression in Col-0 28 hours after SA treatment, suggesting the interaction between plant basal defense response and SA pathway (Additional file 2).

Overall, the expression patterns of the NBS-LRR-encoding and related genes detected in the above microarray experiments were generally consistent among array experiments. Most genes were detected as expressed at low levels and not induced by treatment with defense signals.

Five of the mRNA samples that were used to generate the Arabidopsis MPSS libraries described above (LEF, CAF, INF, ROF, and SIF MPSS libraries; [75-77]) were also analyzed using ATH1 arrays to cross-validate the two approaches. The expression patterns of the NBS-LRRencoding and related genes detected in the microarray experiment were generally consistent with the MPSS data (Table 2; Additional file 1). These 162 genes showed different expression levels in different tissues. For example, both the MPSS data and Affymetrix array data indicated that At4g16990 has its highest expression in leaf, lower expression in flowers and siliques, and its lowest expression in callus and root. Most genes were usually the most highly expressed in callus; expression levels in flowers and siliques were similar (Figure 1). Forty-six of the 67 genes with undetectable levels of expression in the leaf sample in the microarray analysis had 0 MPSS tags in the leaf MPSS library (LEF), while 75 of the 95 genes detected by microarray analysis had more than one tag in the MPSS leaf library. For 88 NBS-LRR-encoding and related genes which are represented by unique MPSS tags and probe sets on the ATH1 array, Spearman rank correlation test showed a good correlation between MPSS data and
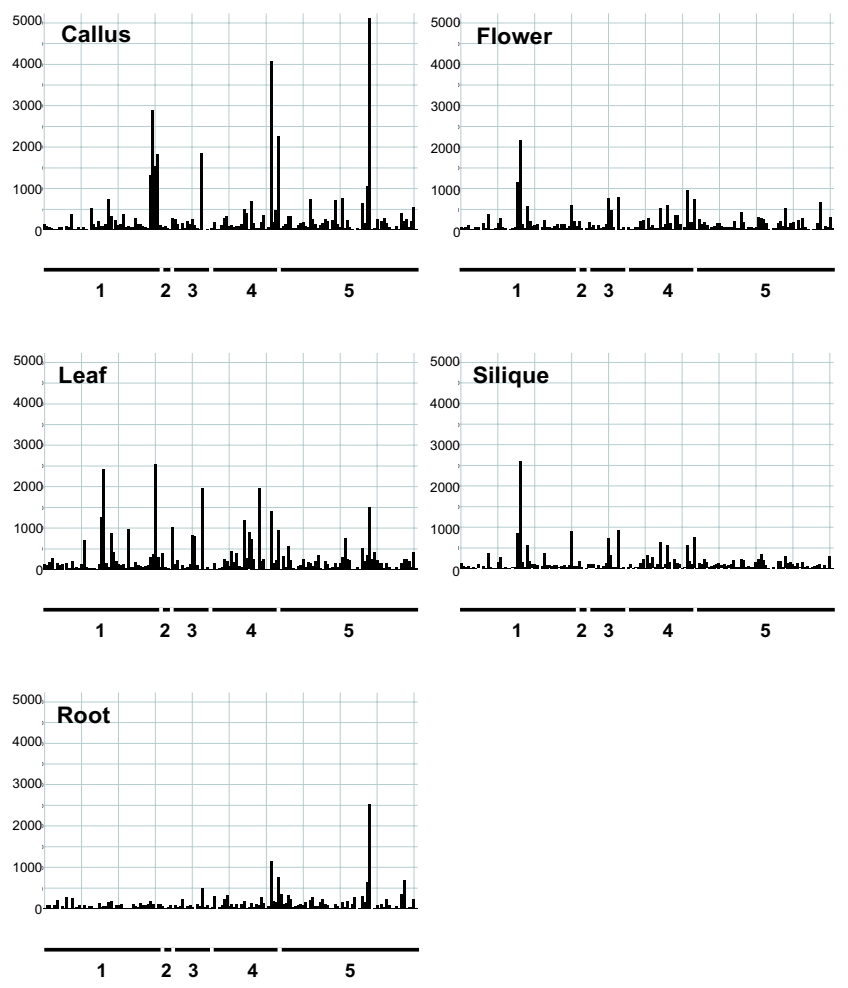

Figure I

The expression level of 162 NBS-LRR-encoding and related genes in five different tissues of Arabidopsis wild-type Col-0. All NBS-LRR-encoding and related genes are ordered according to their At numbers along the $X$ axis. Each Arabidopsis chromosome is indicated below each graph. $Y$-axis indicates the relative expression level of each probe set after scaling the mean intensity of each ATHI microarray to 500 .

Affymetrix array data generated from the same leaf tissue (correlation coefficient $0.74357, P$-value $<0.001$ ).

\section{Reporter gene traps}

We attempted to use enhancer and gene trap lines in parallel to the above global analyses, to gain information on cell-specific expression patterns for individual NBS-LRRencoding or related genes and to investigate their inducibility in greater detail. Gene traps and enhancer traps contain insertions of the $\beta$-glucuronidase (GUS) reporter gene under the control of no promoter or a minimal promoter respectively [81-83]. The expression pattern of a gene with a reporter gene inserted within it or nearby can be monitored via expression of the reporter gene. Gene trap and enhancer traps also allow the analysis of the mutant phenotypes resulting from the disruption of chromosomal genes [81-84].

The Cold Spring Harbor database of flanking sequences for Arabidopsis Gene Trap lines [85] and the database of the Ds insertion lines from Singapore IMA (Institute of 
Molecular Agrobiology, [86]) were searched in 2002 for insertions in NBS-LRR-encoding and related genes using BLAST. Ten enhancer trap lines and three gene trap lines were identified with insertions into NBS-LRR-encoding or related genes. The insertion sites and orientations were confirmed for seven enhancer trap lines with insertions into five NBS-LRR-encoding genes and two TIR-NBSencoding genes (Table 5, Figures 2 and 3). No gene trap lines were confirmed.

The expression pattern of the corresponding NBS-LRRencoding and related gene in each confirmed enhancer trap line was analyzed using GUS staining and quantitative GUS assays of seedlings and five-week old plants. No GUS activity was detected histochemically in whole seedling, leaves, roots, flowers and stems of any of the five NBS-LRR and one TIR-NBS enhancer trap lines. This indicated that the low levels of expression detected in the microarray and MPSS experiments for these genes were below the detection threshold of GUS assays in these enhancer trap lines. We found no evidence that any specific cell types exhibited localized, high levels of expression as has been observed for insertions into some other types of genes $[81,87,88]$. In the enhancer trap line with an insertion into a TIR-NBS-encoding gene, At1g72910, there was very faint blue color throughout the leaf after staining for GUS activity. This low level of GUS activity was confirmed using a GUS quantitative assay (Figure 4). At1g72910 was one of the more highly expressed genes detected in the MPSS libraries and microarray data in Col0 leaves (Table 5). These data indicate the threshold necessary for histochemical detection of gene activity in gene trap lines.

These seven NBS-LRR-encoding and related genes were not induced by either salicylic acid (SA) or flagellin treatments in the above microarray experiments. To investigate the possibility that detectable changes in expression occurred transiently at time points not examined in the microarray experiments, jasmonic acid (JA) or benzothiadiazole (BTH) was applied to each of the enhancer trap plants. Neither GUS staining nor quantitative GUS assays provided evidence of induced expression of any the five NBS-LRR-encoding genes and one TIR-NBS-encoding gene in response to BTH or JA (data not shown). The expression of At1g72910, on the other hand, was induced approximately two-fold five days after treatment with BTH (Figure 4), although significant induction by SA had not been detected in the microarray analysis. To examine the possibility that changes in expression occurred in a restricted number of cells at sites of pathogen penetration, each of the seven enhancer trap plant was challenged by P. syringae pv. tomato strain DC3000 carrying avrRpt2 or avrRpm1. All lines showed a similar hypersensitive response (HR) as wild-type Landsberg erecta (Ler) plants, which is the genetic background of the enhancer and gene trap lines. There was no observable localized induction of GUS gene expression in the infiltrated area that reacted to the pathogen.

\section{Rapid Amplification of CDNA Ends (RACE) analysis}

The expression of NBS-LRR-encoding and related genes was further studied using RACE-PCR as a sensitive qualitative method to detect expression as well as to define the $5 '$ and 3 ' ends of the transcripts. Confirmation of transcript boundaries was a prerequisite to studies of gene function because approximately a third of the NBS-LRRencoding and related genes in the public database were previously annotated incorrectly and therefore had to be corrected by manual re-annotation [7]. The sequences of our 5' and 3' RACE products were compared with the Arabidopsis genomic sequence to determine the initiation and termination sites of each transcript (Additional file 1 and online database [73]).

Table 5: Summary of enhancer trap lines

\begin{tabular}{|c|c|c|c|c|c|c|}
\hline $\begin{array}{l}\text { Enhancer } \\
\text { trap line }\end{array}$ & $\begin{array}{l}\text { Gene } \\
\text { interrupted }\end{array}$ & $\begin{array}{l}\text { Gene } \\
\text { type }\end{array}$ & RACE -PCR ${ }^{a}$ & GUS staining & Microarray datab & MPSS datac \\
\hline SET6934 & Atlg72870 & $\mathrm{TN}$ & ND & no & I08.3(M) & $1-15(14)$ \\
\hline SET7I57 & Atlg65850 & TNL & ND & no & $55.4(\mathrm{~A})$ & $3-18(4)$ \\
\hline SET3935 & At5gI7680 & TNL & ND & no & $54.4(\mathrm{~A})$ & $3-3(1)$ \\
\hline SET7450 & Atlg59780 & CNL & ND & no & $41.6(\mathrm{~A})$ & $3-45(3)$ \\
\hline SET6003 & Atlg61300 & $\mathrm{NL}$ & Expressed & no & $\begin{array}{l}552.5(\mathrm{P}) \text { (probe set cross- } \\
\text { hybridizes to Atlg6II80, } \\
\text { At Ig6II90, and At Ig6I310) }\end{array}$ & $\begin{array}{l}\text { 4-I79(37), MPSS tags also } \\
\text { represent Atlg6II80, } \\
\text { Atlg6II90, and Atlg61310. }\end{array}$ \\
\hline ETI927 & Atlg72910 & $\mathrm{TN}$ & Expressed & $\begin{array}{l}\text { Weak staining in leaf; } \\
\text { weak induction by BTH }\end{array}$ & $\begin{array}{l}5566.9(\mathrm{P}) \text { (probe set cross- } \\
\text { hybridizes to At I g72930) }\end{array}$ & $\begin{array}{l}2-127(5), \text { two MPSS tags also } \\
\text { represent other genes. }\end{array}$ \\
\hline ET6374 & $\begin{array}{l}\text { RPP5 (At4gl6950 } \\
\text { in Col) }\end{array}$ & $\mathrm{TNL}$ & Expressed & no & $\begin{array}{l}\text { I377.5(P) (probe set may cross- } \\
\text { hybridize to At4g I } 6860 \text {, } \\
\text { At4g|6890, and At4g|6920) }\end{array}$ & $\begin{array}{l}3-168(3 I) \text {, several MPSS tags also } \\
\text { represent several other genes }\end{array}$ \\
\hline
\end{tabular}

a ND = no detectable expression.

b Called present $(P)$, marginal $(M)$, or absent $(A)$ in microarray expression data in control leaf sample of SA experiment [79].

c Range of adjPPM or TPM (\# of libraries with expression detected). 


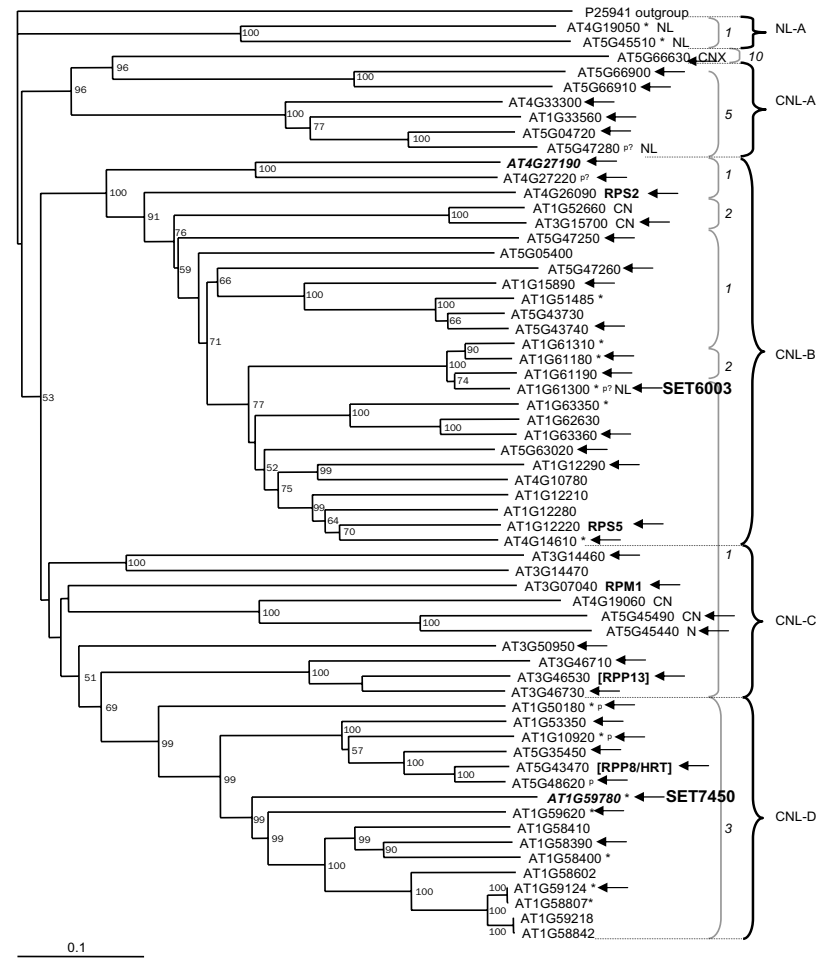

Figure 2

The distribution of CC-NBS-LRR-encoding and related genes analyzed on neighbor-joining tree generated by Meyers et al. [7]. The genes studied by RACE are indicated by black arrows, the genes analyzed using RT-PCR are displayed in bold italic, and NBS-LRR-encoding and related genes with enhancer trap insertions are marked in bold. Other figure denotations are as described in Meyers et al. [7].

A total of 109 NBS-LRR-encoding and related genes were analyzed using total RNA extracted from leaves of Col-0 as template. At least one RACE product was detected for 81 genes (for 26 out of $35 \mathrm{CNL}$ genes and for 38 out of 50 TNL genes analyzed; Table 2). Both 5 ' and 3 ' products were detected for 68 of these 81 genes. Only $5^{\prime}$ products were detected for another six genes and only $3^{\prime}$ products for an additional seven genes. Neither 5 ' nor 3 ' products were detected for the other 28 genes; the lack of expression of six of these 28 genes in leaves was confirmed using RT-PCR with primers that should have amplified an internal region of the transcript (Figures 2 and 3, Table 2). RACE for six NBS-LRR-encoding genes that were not detectable in leaves from four-week old plants was also conducted using total RNA extracted from seven-day old seedlings as templates. RACE again failed to detect expression of five of these genes, At2g17050, At3g46730, At4g08450, At4g09360, and At4g27190. RACE products were only detected for At1g65850 in seedlings. For two NBS-LRR-encoding genes, At3g44400 and At4g33300, RACE was also performed using the total RNA extracted from flowers as templates in addition to the templates generated from leaf and young seedlings. The RACE results revealed that the expression of these two NBS-LRRencoding genes showed different expression pattern in leaves, seedlings, and flowers. At4g33300 was expressed highest in seedlings, and then the flower and leaf tissues, while At3g44400 was expressed higher in leaves than in flowers.

For the above RACE-PCR products, the length of the $5^{\prime}$ UTR ranged from zero to $241 \mathrm{bp}$ (average $=\sim 50 \mathrm{bp}$ ); most $5^{\prime}$ transcription start sites were within $100 \mathrm{bp}$ of the ATG start codon. There was some variation in the transcription initiation site and often multiple initiation sites were detected for each gene. The length of the 3' UTR ranged from 6 bp to 896 bp and most 3' UTRs were several hundred bp long (average $=\sim 250 \mathrm{bp}$ ). The most common variation in 3'UTRs was due to alternative polyadenylation sites. Comparison of RACE and genomic sequences revealed that 15 genes contained introns in their $5^{\prime}$ or 3' UTR regions. Seven genes had one intron and one had two introns in their 5' UTRs. Six genes had one intron and one had three introns in their 3'UTRs. The presence of introns in either 5' or 3' UTRs has also been indicated in the TAIR database [89]. Six out of eight genes which have introns in their 5' UTR according to our RACE results have also been annotated as having introns in the TAIR database, and similarly five out of seven genes which have introns in 3 ' UTR have also been so annotated in the TAIR database.

Sequence analysis of the RACE-PCR products revealed that the annotations of 12 NBS-LRR-encoding and related genes in the TAIR database were incorrect or at least inconsistent with our experimental data (Additional file 1). These genes had been annotated with incorrect transcript initiation or termination sites, different splicing sites, or extra exons. The RACE-PCR products validated the previous manual re-annotations for six genes [7]. The errors in the other six genes had not previously been detected. These six genes had different splicing events from those predicted. RACE-PCR data also revealed the presence of alternative splicing in the 5'UTR of At1g10920 and 3'UTR of At1g72860, in addition to the four genes which were indicated by MPSS data as exhibiting alternative splicing and had been confirmed by RACE-PCR and sequencing.

\section{Discussion}

Our comprehensive expression analysis revealed that the majority of NBS-LRR-encoding and related genes in Arabidopsis were expressed at low levels and unexpectedly that many exhibited tissue-specific expression patterns (Additional file 1). The expression of some but not the majority of NBS-LRR-encoding and related genes was affected by treatments with defense signaling chemicals. The expression pattern of most of the previously uncharacterized 


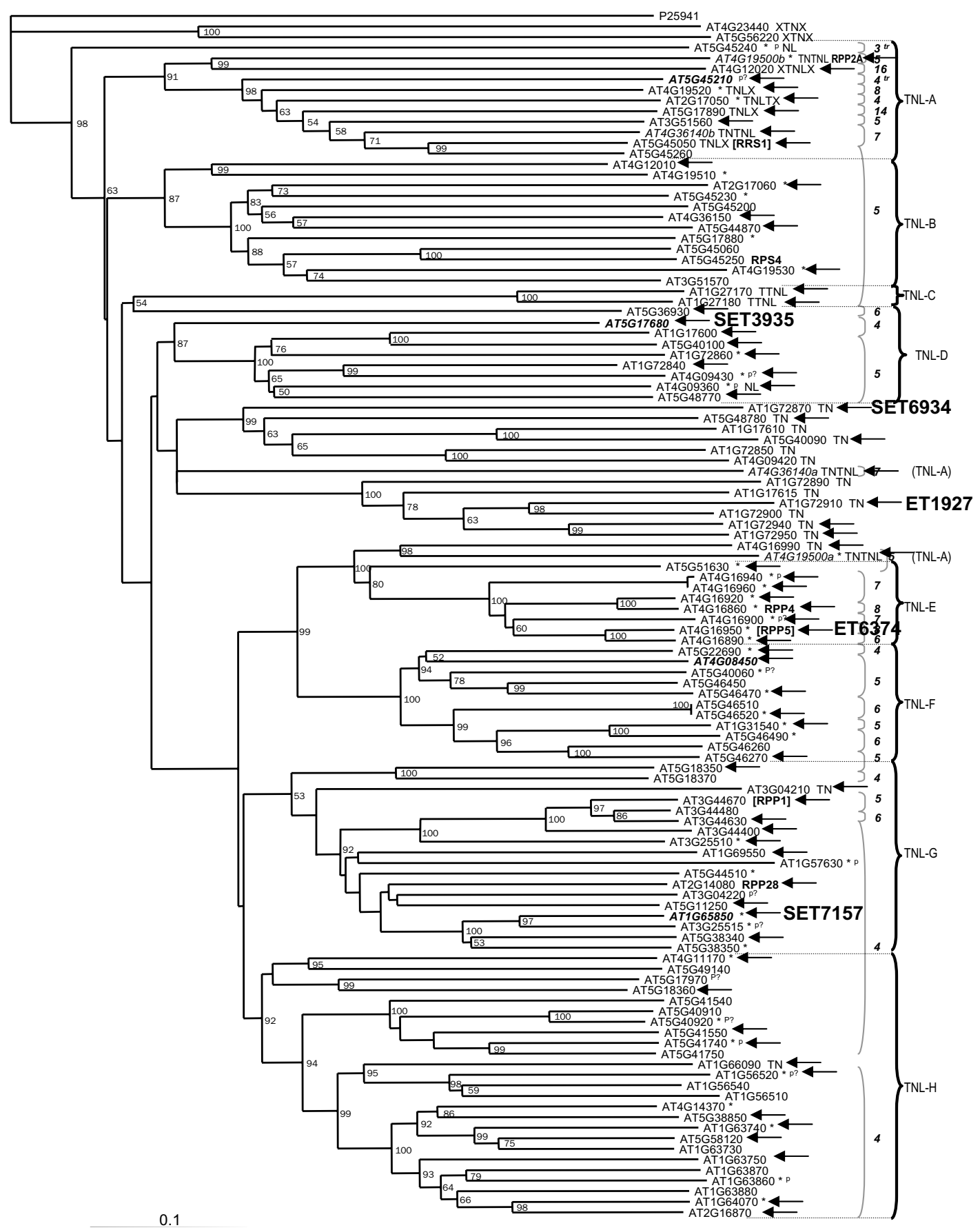

Figure 3

The distribution of TIR-NBS-LRR-encoding and related genes analyzed on neighbor-joining tree generated by Meyers et al. [7]. The genes studied by RACE are indicated by black arrows, the genes analyzed using RT-PCR are displayed in bold italic, and NBS-LRR-encoding and related genes with enhancer trap insertions are marked in bold. Other figure denotations are as described in Meyers et al. [7].

NBS-LRR-encoding and related genes resembles that of known $R$ genes and therefore is consistent with these genes also functioning in disease resistance.

\section{Consistency between different analytical approaches}

The different analytical approaches varied in their sensitivity and accuracy, but the expression data obtained from each approach were generally consistent. Both MPSS and 


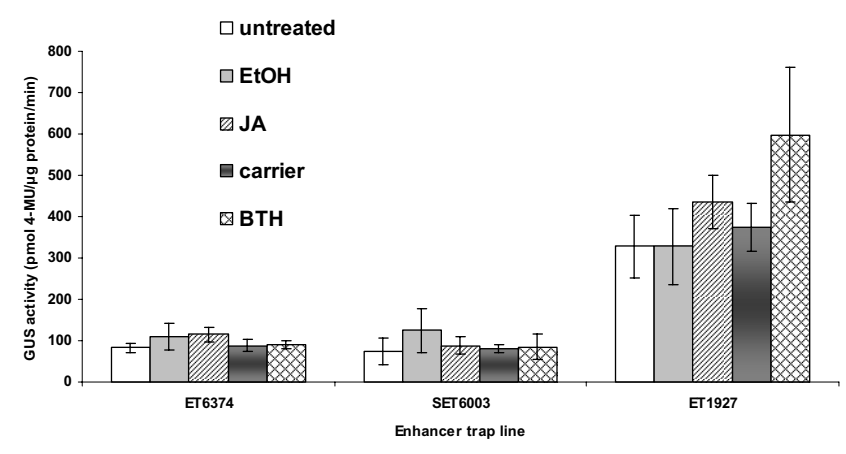

Figure 4

GUS quantitative assays of enhancer trap lines with insertions into two NBS-LRR-encoding and one related gene. GUS expression levels of each enhancer trap line untreated or five days after application of JA or BTH. Treatments with ethanol $(\mathrm{EtOH})$ or BTH carrier (carrier) were used as controls. Average GUS expression levels and standard deviations were based on three biological replicates. The background levels of GUS activity in untreated

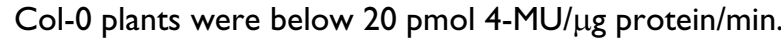

microarrays were the most efficient genome-wide transcript profiling methods and they correlated well. MPSS has several advantages over microarray analysis. MPSS is more sensitive and accurate, since MPSS provides quantitative assessment of the abundance of each transcript as opposed to the hybridization intensity generated for each probe set in the microarray analysis. MPSS is particularly advantageous for genes that are expressed at low levels and therefore tend to be more affected by background noise in microarray analysis. For example, both At5g45230 and At1g17600 were expressed at undetectable levels in microarray analysis of leaf tissue; however, based on MPSS data, At1g17600 was expressed clearly higher than At5g45230 in the leaf library (14 vs 0 TPM) (Additional file 1). MPSS can also distinguish multi-gene family members better than microarrays and therefore decrease cross-hybridization problems, which is more common in microarray analysis. Inconsistencies between MPSS and microarray data could have been due to crosshybridization problems in the microarray analysis or due to some MPSS tags representing several gene family members that had high sequence similarity. In addition, sequencing errors in the current Arabidopsis genome assembly may have caused incorrect assignment of some MPSS tags and thus inaccurate determination of expression. While MPSS has the above advantages, its technical accessibility and high cost limit its widespread use, although these issues may be ameliorated with the latest sequencing technologies. Microarrays therefore remain a useful complement to investigate situations for which MPSS data do not exist until other high throughput sequencing technologies become available that allow affordable, in depth analysis of EST representation.

\section{Expression levels of NBS-LRR-encoding genes}

The majority of NBS-LRR-encoding and related genes examined in this study were expressed at low levels in unchallenged plants similar to what has been observed for most cloned plant $R$ genes. Significant changes in expression of most NBS-LRR-encoding and related genes including the known $R$ genes were not detected during plant defense responses or treatments with two defense signaling molecules, SA or JA. Other recent RNA profiling experiments also failed to detect differential expression of $R$ genes [90,91]. Similarly, in another microarray experiment performed to study gene expression changes during the resistance response, none of the Arabidopsis NBSLRR-encoding genes showed significant expression changes during the plant defense response mediated by RPS2, RPM1, RPS5, or RPS4 (A. Bent et al., unpublished). This lack of induction of gene expression during plant defense response resembles that of most known plant $R$ genes. Although it is still not clear how plant $\mathrm{R}$ proteins function in the plant defense response, it is clear that they act at an early step in defense signaling pathways, either as primary recognition molecules or accessory proteins [1416,92-94]. Low levels of constitutive expression of R proteins are consistent with a constitutive ability to recognize the pathogen infection and induce downstream defense responses.

There are, however, several indications of transcriptional control of $R$ gene expression. At least a subset of $R$ genes are induced above their low levels of constitutive expression during the elicitation of basal resistance; the expression of RPS2, RPM1, and eight other NBS-LRR-encoding and related genes was induced by the bacterial flagellin peptide, flg22 [78]. This can be thought of increasing the general sensitivity of the plant to detect potential pathogens. Our analysis also revealed that fifteen NBS-LRRencoding and related genes in wild-type Col-0, including the Col-0 homolog of RPP4, were induced 4 hours after treatment with SA; also several other genes were induced by SA in other accessions. Interestingly, out of the fifteen NBS-LRR-encoding and related genes induced by SA in Col-0, two genes also exhibited elevated expression induced by flg22. This overlap suggests interactions between plant basal defense response and SA signaling pathways. The MPSS data indicated that expression of many NBS-LRR-encoding and related genes was also affected by plant developmental stage or treatments with sucrose or the plant hormone ABA. In addition, our gene trap studies of a limited number of $R$ gene related sequences demonstrated the induction of the expression of one TIR-NBS-encoding gene, At1g72910, by the SA homolog, BTH. A previous transcript profiling experiment 
in Arabidopsis also revealed the expression of several NBS-LRR-encoding and related genes was altered during defense response to cucumber mosaic virus strain $\mathrm{Y}$; the expression of one TIR-NBS-LRR-encoding gene, At1g56510, and one TIR-X-encoding gene, At1g65400, was down-regulated, and that of two other TIR-X-encoding genes, At1g72940 and At1g72920, was induced [95]. These results all provide evidence for regulation of $R$ gene expression during plant defense response and the induction of enhanced levels of defense-related surveillance in response to biotic challenge.

\section{Tissue specificity}

An unexpected result from the current study was the frequent tissue-specific expression patterns exhibited by NBS-LRR-encoding and related genes. Both the MPSS data and the microarray data demonstrated that many NBSLRR-encoding and related genes showed tissue specificity. Some genes were mainly expressed in aerial parts of plants, while some genes were specifically expressed in roots. Others appeared to be developmentally regulated. These patterns of differential expression suggest either that NBS-LRR-encoding and related genes function in resistance to a variety of pathogens that attack different parts of the plant, or that some NBS-LRR-encoding and related genes function in different plant biological processes. Previous to our studies there was little data on the tissue specificity of known $R$ genes. All of the 14 known NBS-LRR-encoding $R$ genes or their Col-0 homologs analyzed in our study exhibited tissue specific gene expression. Interestingly, the tomato NBS-LRR-encoding $R$ gene, $I-2$, is expressed at the site of lateral root formation indicating that it might have a role in lateral root initiation in addition to disease resistance [38].

\section{Alternative transcripts}

Alternative splicing was detected for several NBS-LRRencoding genes. Twelve NBS-LRR-encoding genes showed evidence of alternative splicing based on the locations of MPSS tags and four of these genes, including the Col-0 homologs of two known $R$ genes, RPP5 and RPP4, were confirmed by RACE-PCR and subsequent sequencing. The alternative transcripts of two genes (At1g63750 and At4g16860) encode truncated proteins containing only the majority of TIR domain and lacking both the NBS and LRR domains. The alternative transcript of At5g46270 encodes a truncated protein lacking most of the LRR domain, while alternative transcripts of At4g16950 encode TIR-NBS-LRR proteins with only the last few amino acids altered. The alternative splicing in At1g10920 and At1g72860 which was revealed by RACE-PCR occurs in the $5^{\prime}$ or $3^{\prime}$ UTR and therefore does not change the amino acid sequence; however, such alternative splicing could affect transcript stability and therefore the expression level. Alternative splicing has been reported for seven known TIR-NBS-LRR-encoding $R$ genes and one CC-NBSLRR-encoding $R$ gene [46,49-55]. Based on alignments of genomic sequences with full-length CDNA and EST sequences, 1186 Arabidopsis genes in the TIGR database [96] have been annotated as undergoing splicing variation and have been classified into five different types of splicing variants. Although ten NBS-LRR-encoding or related genes are included in these 1186 genes, only one gene was identified as exhibiting alternative splicing by MPSS or RACE analysis in our studies. A recent extensive computational analysis [97] identified alternative splicing events in 4707 Arabidopsis genes including 16 NBS-LRR-encoding and related genes. Seven out of these 16 genes were also identified in TIGR database; however, only two out of these 16 genes were also detected as showing alternative splicing by MPSS or RACE analysis in our studies. This inconsistency may be due to RACE and MPSS tending to analyze sequences at the ends of transcript or due to the lack of sampling the appropriate tissues or conditions. Together, these data indicate that at least 22 TIR-NBS-LRRencoding, one TIR-NBS-encoding, one divergent NBSLRR-encoding, and eight CC-NBS-LRR-encoding genes exhibit alternative splicing in Arabidopsis.

The role of alternative splicing in plant $R$ genes is unclear. The splice variants might interact with the full length $R$ protein and have a regulatory role in disease resistance as has been suggested for the tobacco $N$ and Arabidopsis RPS4 genes. This is similar to the role of alternative splicing in animal toll-like receptor (TLRs) [98]. The alternative transcript of the tobacco $N$ gene is induced by challenge with tobacco mosaic virus and the ratio of the two transcripts appears to be critical for resistance $[50,99]$. The presence of both full-length and alternative transcripts of Arabidopsis RPS4 is necessary for the RPS4mediated defense response $[52,100]$. However, the alternative transcripts of flax $L G$ and tomato $B s 4$ seem not to be important for the resistance that these genes mediate $[49,54]$.

One of the TIR-NBS-encoding genes, At1g72910, may function in plant defense response as indicated by the induction of its expression by a SA analog, BTH. Similarly, six TIR-NBS-encoding genes, At1g17610, At1g66090, At1g72890, At1g72900, At1g72950, and At3g04210, may also function in plant defense response since their expression was affected by SA treatment in at least one of the seven Arabidopsis ecotypes studied. Two TIR-NBS-encoding genes, At1g72900 and At1g72940, may function in plant basal defense response since their expression was induced by flagellin. In the Arabidopsis Col-0 genome, there are 21 TIR-NBS-encoding genes that have similar structures as the alternative transcripts of the tobacco $N$, flax L6 or Arabidopsis RPS4 genes [9]. These might func- 
tion similarly to the alternatively transcribed variants of TIR-NBS-LRR-encoding genes.

\section{Post-transcriptional regulation}

$R$ genes do not need to be induced at the transcriptional level in order to alter resistance against pathogens. There are likely to be multiple levels of negative regulation to prevent the inappropriate activation of $\mathrm{R}$ proteins in the absence of pathogen that would be deleterious to plants due to the high cost of the defense response and pathogen-independent cell death. There may also be feedback loops controlling the $R$ gene expression and the extent of HR.

Our study analyzed steady state mRNA levels, which may not reflect protein abundance. Further work is required to identify whether there are differences in the polysomal fraction and what post-translational modifications occur. The expression of several $R$ genes has been reported to be regulated at the post-transcriptional level. The transcript of Arabidopsis RPM1 remains at a low level before and after pathogen attack; however, the RPM1 protein is degraded during HR [101]. The expression of Xa21 gene transcript is independent of plant developmental stage, though the Xa21-conferred resistance is developmentally regulated [102].

Data from animal systems have demonstrated the involvement of the 5'UTR in controlling translation and tissue specific expression $[103,104]$. Several plant $R$ genes contain introns and/or upstream open reading frames (uORFs) in their 5'UTR including barley Mla6 and Arabidopsis RPP1-WsB and RPP1-WsC $[19,105]$. Our RACE analysis revealed that fifteen out of the 81 NBS-LRRencoding and related genes analyzed contained introns in their 5' or 3' UTRs. These 5'UTR features may be indicative of post-transcriptional regulation of these genes.

\section{Conclusion}

Transcripts of most NBS-LRR-encoding and related genes analyzed were present at low levels in unchallenged plants. Many showed tissue specific expression patterns. Transcript levels of the majority of NBS-LRR-encoding and related genes were not altered during the plant defense response or by treatments with plant defense signaling molecules; however, the expression of several genes was altered and may be indicative of altered levels of surveillance by the plant. Our data are consistent with the primary function of the majority of NBS-LRR-encoding and related genes being plant resistance; however, this does not preclude their involvement in functions other than pathogen recognition.

Future studies on the significance of tissue specificity, the roles of alternative transcripts and the relationship between transcript and protein levels will likely be informative as will the characterization of the spectrum of genes induced downstream of each major clade of NBSLRR-encoding genes.

\section{Methods}

\section{Expressed Sequence Tag (EST) analysis}

EST representation for each Arabidopsis NBS-LRR-encoding or related gene was obtained by searching the NCBI EST database using the predicted cDNA sequence or genomic sequence (plus 500 bp upstream and downstream of the predicted start and stop codons) of each NBS-LRR-encoding or related gene [7] using BLAST [106]. As of July $14^{\text {th }}, 2006$, this database contained a total of 622,792 Arabidopsis EST sequences including: short, single read cDNA sequences, cDNA sequences from differential display experiments and RACE analyses, and cDNA sequences from full-length cDNA clones from RIKEN (The Institute of Physical and Chemical Research, Japan) [107]. All Arabidopsis ESTs with matches of greater than $80 \%$ identity to NBS-LRR-encoding and related genes were investigated. EST representation was determined based on the alignment between ESTs and the genomic or cDNA sequence of the corresponding gene and usually showed $>97 \%$ sequence similarity. Each potential representative EST was compared against the complete Arabidopsis genomic and spliced sequences using TAIR BLAST tool [108] to confirm that it was the best match to the represented gene. The ESTs showing best match to a specific NBS-LRR-encoding or related gene but with sequence identity less than $97 \%$ due to obvious sequencing difficulties were also counted. The ESTs that showed the same level of sequence similarity to several closely related family members were counted for each represented gene. A similar analysis was also performed earlier in April 2002 except that FASTA [109] was used to search for sequence similarity. The NCBI EST database contained about 181,406 Arabidopsis sequences at that time.

\section{Massively Parallel Signature Sequencing (MPSS) data}

MPSS provides a comprehensive assessment of gene expression by generating short sequence tags, each 17 to $20 \mathrm{bp}$ long, produced from a defined position (usually the first Sau3A restriction site 5' to the polyadenylation site of a transcript) within each transcript $[67,68]$. The expression level of each gene in a sample is determined by counting the number of diagnostic sequence tags representing the transcript of a particular gene.

The DuPont MPSS database contained expression profiles generated from 22 Arabidopsis MPSS libraries. Half were constructed from Arabidopsis ecotype Columbia (Col-0) or Landsberg erecta (Ler) tissues collected at different developmental stages and half were constructed from wild type or mutant Col-0 or Ler ecotype plants treated with 
various chemicals or hormones including abscisic acid (ABA), dexamethasone (DEX), or sucrose (Table 3). Each library contained approximately one million 17 bp tags. Seventeen additional MPSS libraries were made from various Arabidopsis Col-0 tissues (callus, flower, leaf, silique, and root from wild-type or flowering mutants) or salicylic acid (SA) treated leaf tissues and displayed in the public MPSS database (Table 4, [74-76]). Each of these public libraries contained about two and half million $17 \mathrm{bp}$ tags.

For the analysis of the DuPont MPSS data, searches were performed using the genomic sequence for each NBS-LRRencoding or related gene plus 500 bp upstream and downstream of the predicted start and stop codons. In a few cases the additional flanking sequence overlapped adjacent genes with small intergenic regions; however, these were manually checked and did not contain expressed tags that could have biased the analysis. Each expressed tag was also compared against the complete Arabidopsis genomic and spliced sequences using TAIR BLAST tool [108] to confirm the correct match to the designated gene; only matches to the sense strand were used in the calculations of transcript abundance. The frequency of each tag was counted and then normalized in parts per million (PPM) to calculate the abundance of each transcript in the sample. The PPM values were adjusted (adjPPM) to account for potential sequencing errors (described in [9]). The possible alternative polyadenylations caused by alternative splicing and variable stop codons were predicted based on the tag location. For the Arabidopsis MPSS data generated by Meyers et al. [75,76], a basic query was performed for each gene based on gene "At" number (gene identifier) against the 17 MPSS libraries. To allow comparisons among libraries, the signature frequencies were normalized to transcripts per million (TPM). For genes associated with multiple expressed signatures, the sum of abundance for all expressed signatures, including the signatures with more than one hit to the Arabidopsis genome, was used to indicate the abundance of each transcript in the sample.

In order to investigate potential correlations between gene expression and phylogenetic position, the expression level and tissue specificity of each NBS-LRR-encoding or related gene was compared with the phylogenetic tree described previously [7]. To investigate potential correlations between gene expression pattern and chromosomal location, these NBS-LRR-encoding and related genes were sorted by their gene identifiers, which usually reflects their chromosomal locations, and then the expression pattern of NBS-LRR-encoding and related genes was visually compared to their locations on this sorted gene list.

\section{Microarray analysis}

Concurrent global expression experiments using ATH1 Affymetrix arrays provided the opportunity to assess the expression patterns of NBS-LRR-encoding and related genes.

The experiment analyzing the response to applications of salicylic acid (SA) was described in [79]. Six-week old plants from seven Arabidopsis thaliana accessions (Col-0, Cvi-1, Est, Kin-0, Mt-0, Tsu-1, and Van-0) were sprayed with $0.3 \mathrm{mM}$ SA in $0.02 \%$ Silwet L77. Plants treated with $0.02 \%$ Silwet L77 were used as controls. The aerial parts of the plants were harvested 4, 28 or 52 hours later. Each treatment and time-point was replicated three times. Gene expression levels were assayed using the Affymetrix ATH1 GeneChips. The ATH1 array contains approximately 22,000 genes including 152 probe sets representing 162 NBS-LRR-encoding and related genes based on Affymetrix annotation [110]. Raw data (CEL files) were imported into GeneChip ${ }^{\varpi}$ Operating Software data base (GCOS). Transcript abundances for all probe sets on the Affymetrix ATH1 GeneChips array were analyzed using GCOS. GCOS was also used to assess the presence or absence of a given transcript ( $\mathrm{P}$, present; $\mathrm{A}$, absent; $\mathrm{M}$, marginal) for each probe set. To allow direct comparison between chips, raw signals were globally scaled so that the mean expression level of each array was equal to an arbitrary target intensity of 500. The scaled signals were then imported into Excel for further analysis.

Raw array data (CEL files) of another experiment [78] studying flagellin treated Arabidopsis plants were obtained from ArrayExpress [111]. In this experiment, the Ler accession of Arabidopsis seedlings were treated with $10 \mu \mathrm{M}$ flg22 peptide and plantlets analyzed 30 minutes after treatment. GCOS was used to extract the expression signal and assign a present or absent call for each gene represented by a probe set on the ATH1 array. The data was processed in the same manner as for the SA induction experiment: raw signals were globally scaled to a target intensity of 500 for direct comparison.

Microarray analysis was also performed on the same five total RNA samples used for generating five of the 17 public MPSS libraries. Gene expression levels were also assayed using the ATH1 arrays. Complementary RNA labeling, hybridization, and signal acquisition were performed according to the manufacturer's guidelines (Affymetrix, Santa Clara, CA). Affymetrix Microarray Suite version 5.0 (MAS 5.0) was used to control washing, scanning and data-preprocessing steps. Raw CEL files were then imported into GCOS and GCOS was used to extract the expression signals and assign a present or absent call. To allow direct comparison across chips, raw signals were globally scaled to a target intensity of 500 . 
All data analysis was subsequently performed using GeneSpring GX 7.3.1 software (Agilent Technologies, Santa Clara, CA). The raw output signals from GCOS, without scaling and normalization, were used as input for analysis in GeneSpring GX. The raw signals were first normalized using the 50th percentile of all measurements on a given chip and then the median measurement of each gene was adjusted to 1 . In order to identify differentially expressed genes in response to SA or flagellin, a list of probe sets showing reliable and detectable expression was first established using several criteria. Probe sets were retained if they were called as present or marginal by GCOS in both replicates (or two out of three replicates) of at least one of the two comparison conditions, their coefficient of variation (CV) were less than 0.3 in at least one of the two comparison conditions, and they exhibited at least two fold changes. Starting from this list of genes, the genes exhibiting a significant expression change in a given treatment were identified as those genes passing the parametric test (Welch t-test) in GeneSpring GX, without assuming equal variances and with multiple testing correction (Benjamini and Hochberg False Discovery Rate), and a $P$-value threshold of 0.1 . The log-transformed normalized signals were used when performing these parametric tests.

The expression level polymorphism between seven Arabidopsis accessions for each NBS-LRR-encoding gene was determined using ELP Finder tool [112]. Affymetrix ATH1 GeneChip probeset IDs were entered as query and the average expression value for each gene in a given accession with the standard error was returned. The results of pairwise t-tests between the accessions selected were also returned.

The possible correlation between MPSS and microarray data was analyzed using Spearman rank correlation test conducted in SAS9.1 (SAS Institute, Cary, NC). The MPSS and microarray data analyzed using this test was generated from the same leaf sample and only the 88 NBS-LRRencoding and related genes that had unique representative Affymetrix probe sets and MPSS sequence tags were included.

\section{Plant materials and growth conditions}

Arabidopsis Col-0 plants used for Rapid Amplification of CDNA ends (RACE) analysis were grown in soil (Premier Pro-Mix B mix) in controlled-environment chambers at $21^{\circ} \mathrm{C}$ with $50 \%$ humidity, on a $16 \mathrm{hr}$ light $/ 8 \mathrm{hr}$ dark cycle, and under 100 to $120 \mu \mathrm{Ei}$ illumination.

The gene trap and enhancer trap lines (Landsberg erecta (Ler) background) were obtained from Cold Spring Harbor Laboratory (CSHL) or Singapore Institute of Molecular Agrobiology (IMA) [85,86]. The seedlings from each gene trap line were first selected on 1/2 MS medium agar plates with $50 \mu \mathrm{g} / \mathrm{ml}$ kanamycin and then the surviving seedlings were transferred to soil. These plants were grown in controlled-environment chambers with the same conditions as above.

\section{Analysis of gene trap lines}

The gene traps lines carried the $\beta$-glucuronidase (uidA) reporter gene at sequence-characterized positions [81-84]. The genomic sequences of 207 NBS-LRR-encoding and related genes were searched against the flanking sequence databases of Gene Trap lines generated at Cold Spring Harbor Laboratory (CSHL) [85] and Ds insertion lines generated at Singapore Institute of Molecular Agrobiology (IMA) [86] using BLAST [106]. For each trap line, tissue PCR [113] was performed to confirm the insertion site and determine the orientation of the inserted element by using a gene-specific primer and a uidA specific primer.

To study the induction of NBS-LRR-encoding gene expression, jasmonic acid (JA; $500 \mu \mathrm{M}$ ) was dissolved in $10 \% \mathrm{v} /$ $\mathrm{v}$ ethanol and sprayed onto five-week old plants in sterile containers. Benzothiadiazole (BTH; $1.2 \mathrm{mM}$ ) was dissolved in water with a wettable powder carrier (same amount of carrier as BTH) and similarly sprayed onto the five-week old plants in sterile containers. Treatments with $10 \% \mathrm{v} / \mathrm{v}$ ethanol or the wettable powder carrier were used as controls for each experiment. Whole plants were collected at different time points from 0,24 , and $48 \mathrm{hrs}$, to 5 days after each treatment and then subjected to GUS histochemical staining and GUS activity assays. Each gene trap plant was also challenged with $P$. syringae pv. tomato strain DC3000 carrying avrRpt2 or avrRpm 1 which caused a hypersensitive response (HR) in wild-type Col-0 and Ler plants. The HR response was examined at 16 hours, 1 day and 2 days after pathogen infiltration and GUS staining was performed at the same time.

Histochemical staining for GUS activity was performed according to a slightly modified protocol from $[114,115]$. Plant tissues were immersed in the GUS staining solution (100 mM sodium phosphate (pH7.0), $2 \mathrm{mM} \mathrm{K}_{3} \mathrm{Fe}(\mathrm{CN})_{6}$, $2 \mathrm{mM} \mathrm{K}_{4} \mathrm{Fe}(\mathrm{CN})_{6}, 10 \mathrm{mM}$ EDTA, $0.1 \%$ (v/v) Triton X-100, $100 \mu \mathrm{g} / \mathrm{ml}$ chloramphenicol, with $1 \mathrm{mg} / \mathrm{ml}$ 5-bromo-4chloro-3-indolyl- $\beta$-D-glucuronide cyclohexylammonium salt (X-gluc, Gold Biotechnology Inc., St. Louis, MO, U.S.A.). The plant tissues were incubated with GUS staining solutions at $37^{\circ} \mathrm{C}$ for $24 \mathrm{hrs}$.

GUS activity was quantified fluorometrically using 4methylumbelliferone glucuronide (MUG, Sigma) as a substrate as described by Jefferson et al[114]. Reactions were performed in $200 \mu \mathrm{l}$ of extraction buffer $(50 \mathrm{mM}$ $\mathrm{NaPO}_{4} \mathrm{pH} 7,10 \mathrm{mM}$ EDTA, $0.1 \%$ Triton X-100, 0.1\% Sodium Lauryl Sarcosine, $10 \mathrm{mM} \beta$-mercaptoethanol) containing $1.1 \mathrm{mM}$ MUG and stopped after $1 \mathrm{~h}$ incuba- 
tion at $37^{\circ} \mathrm{C}$ by addition of $800 \mu \mathrm{l} 0.2 \mathrm{M} \mathrm{Na}_{2} \mathrm{CO}_{3}$. The fluorescence was calibrated using 4-methylumbelliferone (MU, Sigma, St. Louis, MO, USA). Total protein was determined using Bradford reagents and BSA as a standard [116].

\section{Rapid Amplification of cDNA Ends (RACE)-PCR}

RACE-PCR was performed with the Marathon ${ }^{\mathrm{TM}}$ cDNA Amplification Kit (Clontech, Mountain View, CA, USA) according to the manufacturer's instructions. Total RNA was extracted from the leaves of about four-week old wildtype Arabidopsis Col-0 plants, seven-day old seedlings, or flower tissues using the TRIzol procedure (Invitrogen, Carlsbad, CA). Template mRNA was then purified from total RNA using Dynabeads ${ }^{\circledR}$ Oligo $(\mathrm{dT})_{25}$ (Dynal Biotech, Lake Success, NY, USA). RACE-PCR products were cloned into the $\mathrm{pCR}^{\circledR} 2.1-\mathrm{TOPO}^{\circledR}$ vector (Invitrogen, Carlsbad, $\mathrm{CA})$ and sequenced. Sequence data were analyzed using BLAST and Sequencer 3.1 (GeneCodes, Ann Arbor, MI). All RACE sequences were deposited into NCBI GenBank under accession numbers from ES444179 to ES444640 and from EX654484 to EX654486.

\section{Reverse Transcription-PCR (RT-PCR)}

RT-PCR was carried out using Advantage ${ }^{\mathrm{TM}}$ RT-for-PCR Kit (Clontech, Mountain View, CA) according to the manufacturer's instructions. Primers were designed to amplify regions containing an intron in order to distinguish genomic DNA contamination from gene transcripts.

\section{Authors' contributions}

XT conducted the majority of the experiments, analyzed the data and drafted the paper. BCM assisted in the experimental design, data analysis and writing. AK provided bioinformatics support for analysis of EST and genomic Arabidopsis sequences and data visualization. MALW and DAStC contributed the microarray experiments on the Arabidopsis accessions and the SA treatment as well as assisted in data interpretation. MM contributed MPSS data. AFB contributed to the experimental design and writing. RWM contributed to the overall experimental design, data interpretation, and writing of the paper.

\section{Additional material}

\section{Additional file 1}

Detailed summary of expression analyses of NBS-LRR-encoding and related genes. Worksheet $1 \mathrm{~A}$ provides the data structure of worksheet $1 \mathrm{~B}$ and $1 C$. Worksheet $1 B$ provides full expression data of CC-NBS-LRRencoding and related genes. Worksheet $1 C$ provides full expression data of TIR-NBS-LRR-encoding and related genes. Data is also available online [73].

Click here for file

[http://www.biomedcentral.com/content/supplementary/1471-

2229-7-56-S1.xls]

\section{Additional file 2}

The 38 NBS-LRR-encoding and related genes showing altered expression in at least one of three time points $(4,28$, or $52 \mathrm{hrs})$ post treatment with salicylic acid in multiple accessions of Arabidopsis or following treatment with flagellin in wild-type Ler (raw data from [79] and [78], respectively). Fold change values are presented for each treatment $x$ control comparison. Red indicates statistically significant up-regulation; blue indicates statistically significant down-regulation. Columns $5-13$ display data from different ecotypes treated with SA. Column 14 contains data from Ler treated with flagellin. NBS-LRR-encoding and related genes that did not show statistically significant changes are not shown.

Click here for file

[http://www.biomedcentral.com/content/supplementary/14712229-7-56-S2.xls]

\section{Acknowledgements}

We thank Dean Lavelle for technical assistance and Huaqin Xu for bioinformatics support as well as Belinda Martineau for editorial assistance. This work was supported by NSF Plant Genome Program award \# 997597I to R.W.M., A.F.B. et al. and utilized microarray data generated by NSF 2010 Program award \# 0115109 to D.A.St C., R.W.M. et al., and MPSS data generated by NSF Plant Genome Research award \#0I 10528 to B.C.M.

\section{References}

I. Hammond-Kosack KE, Jones JD: Plant Disease Resistance Genes. Annu Rev Plant Physiol Plant Mol Biol 1997, 48:575-607.

2. Dangl JL, Jones JD: Plant pathogens and integrated defence responses to infection. Nature 200I, 4 I I (6839):826-833.

3. Staskawicz BJ, Mudgett MB, Dangl JL, Galan JE: Common and contrasting themes of plant and animal diseases. Science 200I, 292(5525):2285-2289.

4. Martin GB, Bogdanove AJ, Sessa G: Understanding the functions of plant disease resistance proteins. Annual review of plant biology 2003, 54:23-61.

5. Meyers BC, Dickerman AW, Michelmore RW, Sivaramakrishnan S, Sobral BW, Young ND: Plant disease resistance genes encode members of an ancient and diverse protein family within the nucleotide-binding superfamily. Plant J 1999, 20(3):3 I7-332.

6. Pan Q, Wendel J, Fluhr R: Divergent evolution of plant NBSLRR resistance gene homologues in dicot and cereal genomes. Journal of molecular evolution 2000, 50(3):203-2I3.

7. Meyers BC, Kozik A, Griego A, Kuang H, Michelmore RW: Genome-wide analysis of NBS-LRR-encoding genes in Arabidopsis. The Plant cell 2003, I 5(4):809-834.

8. McHale L, Tan X, Koehl P, Michelmore RW: Plant NBS-LRR proteins: adaptable guards. Genome biology 2006, 7(4):2I 2.

9. Meyers BC, Morgante M, Michelmore RW: TIR-X and TIR-NBS proteins: two new families related to disease resistance TIRNBS-LRR proteins encoded in Arabidopsis and other plant genomes. Plant J 2002, 32(I):77-92.

10. Richly E, Kurth J, Leister D: Mode of amplification and reorganization of resistance genes during recent Arabidopsis thaliana evolution. Mol Biol Evol 2002, I9(I):76-84.

II. Monosi B, Wisser RJ, Pennill L, Hulbert SH: Full-genome analysis of resistance gene homologues in rice. Theor Appl Genet 2004, I09(7): | $434-1447$.

12. Van der Biezen EA, Jones JD: Plant disease-resistance proteins and the gene-for-gene concept. Trends in biochemical sciences 1998, 23( I 2):454-456.

13. Innes RW: Guarding the goods. New insights into the central alarm system of plants. Plant physiology 2004, I 35(2):695-70 I.

14. Dodds PN, Lawrence G], Catanzariti AM, Teh T, Wang Cl, Ayliffe $M A$, Kobe B, Ellis JG: Direct protein interaction underlies genefor-gene specificity and coevolution of the flax resistance genes and flax rust avirulence genes. Proceedings of the National Academy of Sciences of the United States of America 2006, I 03(23):8888-8893. 
15. Jones JD, Dangl JL: The plant immune system. Nature 2006, 444(7 I I 7):323-329.

16. Shen QH, Saijo Y, Mauch S, Biskup C, Bieri S, Keller B, Seki H, Ulker $B$, Somssich IE, Schulze-Lefert P: Nuclear activity of MLA immune receptors links isolate-specific and basal diseaseresistance responses. Science 2007, 3 I 5(58 I 5): 1098-II 03.

17. Parniske M, Hammond-Kosack KE, Golstein C, Thomas CM, Jones DA, Harrison K, Wulff BB, Jones JD: Novel disease resistance specificities result from sequence exchange between tandemly repeated genes at the Cf-4/9 locus of tomato. Cell 1997, 9 |(6):82I-832.

18. Thomas CM, Jones DA, Parniske M, Harrison K, Balint-Kurti PJ, Hatzixanthis K, Jones JD: Characterization of the tomato $\mathrm{Cf}-4$ gene for resistance to Cladosporium fulvum identifies sequences that determine recognitional specificity in Cf-4 and Cf-9. The Plant cell 1997, 9(1 2):2209-2224.

19. Botella MA, Parker JE, Frost LN, Bittner-Eddy PD, Beynon JL, Daniels MJ, Holub EB, Jones JD: Three genes of the Arabidopsis RPP I complex resistance locus recognize distinct Peronospora parasitica avirulence determinants. The Plant cell 1998, I O(I I): I847-1860.

20. McDowell JM, Dhandaydham M, Long TA, Aarts MG, Goff S, Holub $E B$, Dangl JL: Intragenic recombination and diversifying selection contribute to the evolution of downy mildew resistance at the RPP8 locus of Arabidopsis. The Plant cell 1998, I O(I I): |86I-I874.

21. Meyers BC, Shen KA, Rohani P, Gaut BS, Michelmore RW: Receptor-like genes in the major resistance locus of lettuce are subject to divergent selection. The Plant cell 1998 I0(II): I833-1846.

22. Wang GL, Ruan DL, Song WY, Sideris S, Chen L, Pi LY, Zhang S, Zhang Z, Fauquet C, Gaut BS, Whalen MC, Ronald PC: Xa2ID encodes a receptor-like molecule with a leucine-rich repeat domain that determines race-specific recognition and is subject to adaptive evolution. The Plant cell 1998, 10(5):765-779.

23. Ellis JG, Lawrence GJ, Luck JE, Dodds PN: Identification of regions in alleles of the flax rust resistance gene $L$ that determine differences in gene-for-gene specificity. The Plant cell 1999, I I(3):495-506.

24. Noel L, Moores TL, van Der Biezen EA, Parniske M, Daniels MJ, Parker JE, Jones JD: Pronounced intraspecific haplotype divergence at the RPP5 complex disease resistance locus of Arabidopsis. The Plant cell I999, I I(I I):2099-2 I I2.

25. Dodds PN, Lawrence G], Ellis JG: Six amino acid changes confined to the leucine-rich repeat beta-strand/beta-turn motif determine the difference between the $P$ and $P 2$ rust resistance specificities in flax. The Plant cell 200I, I3(I):163-178.

26. Wulff BB, Thomas CM, Smoker M, Grant M, Jones JD: Domain swapping and gene shuffling identify sequences required for induction of an Avr-dependent hypersensitive response by the tomato Cf-4 and Cf-9 proteins. The Plant cell 200I, I3(2):255-272.

27. Hwang CF, Williamson VM: Leucine-rich repeat-mediated intramolecular interactions in nematode recognition and cell death signaling by the tomato resistance protein $\mathrm{Mi}$. Plant J 2003, 34(5):585-593.

28. Luck JE, Lawrence GJ, Dodds PN, Shepherd KW, Ellis JG: Regions outside of the leucine-rich repeats of flax rust resistance proteins play a role in specificity determination. The Plant cell 2000, I 2(8): | 367-1377.

29. Warren RF, Henk A, Mowery P, Holub E, Innes RW: A mutation within the leucine-rich repeat domain of the Arabidopsis disease resistance gene RPS5 partially suppresses multiple bacterial and downy mildew resistance genes. The Plant cell 1998, I0(9): 1439-1452.

30. Moffett P, Farnham G, Peart J, Baulcombe DC: Interaction between domains of a plant NBS-LRR protein in disease resistance-related cell death. The EMBO journal 2002, 2I( I7):45II-45I9.

3I. Belkhadir Y, Subramaniam R, Dangl JL: Plant disease resistance protein signaling: NBS-LRR proteins and their partners. Current opinion in plant biology 2004, 7(4):391-399.

32. Jones DA, Takemoto D: Plant innate immunity - direct and indirect recognition of general and specific pathogen-associated molecules. Current opinion in immunology 2004, 16(I):48-62.
33. van der Biezen EA, Jones JD: The NB-ARC domain: a novel signalling motif shared by plant resistance gene products and regulators of cell death in animals. Curr Biol 1998, 8(7):R226-7.

34. Tameling WI, Elzinga SD, Darmin PS, Vossen JH, Takken FL, Haring MA, Cornelissen BJ: The tomato $\mathbf{R}$ gene products $\mathbf{I}-2$ and MI-I are functional ATP binding proteins with ATPase activity. The Plant cell 2002, I 4(I I):2929-2939.

35. Tameling WI, Vossen JH, Albrecht M, Lengauer T, Berden JA, Haring MA, Cornelissen BJ, Takken FL: Mutations in the NB-ARC domain of I-2 that impair ATP hydrolysis cause autoactivation. Plant physiology 2006, I 40(4): I 233-I 245.

36. Faigon-Soverna A, Harmon FG, Storani L, Karayekov E, Staneloni RJ, Gassmann W, Mas P, Casal JJ, Kay SA, Yanovsky MJ: A constitutive shade-avoidance mutant implicates TIR-NBS-LRR proteins in Arabidopsis photomorphogenic development. The Plant cell 2006, I8(I I):2919-2928.

37. Moutinho A, Hussey PJ, Trewavas AJ, Malho R: cAMP acts as a second messenger in pollen tube growth and reorientation. Proceedings of the National Academy of Sciences of the United States of America 200I, 98( I 8): 1048I-10486.

38. Mes J], van Doorn AA, Wijbrandi J, Simons G, Cornelissen BJ, Haring MA: Expression of the Fusarium resistance gene I-2 colocalizes with the site of fungal containment. Plant J 2000, 23(2): $183-193$

39. Clark SE, Williams RW, Meyerowitz EM: The CLAVATAI gene encodes a putative receptor kinase that controls shoot and floral meristem size in Arabidopsis. Cell 1997, 89(4):575-585.

40. $\mathrm{Li} \mathrm{J}$, Chory J: A putative leucine-rich repeat receptor kinase involved in brassinosteroid signal transduction. Cell 1997. 90(5):929-938

4I. Jeong S, Trotochaud AE, Clark SE: The Arabidopsis CLAVATA2 gene encodes a receptor-like protein required for the stability of the CLAVATAI receptor-like kinase. The Plant cell 1999, II( I 0): 1925-1934

42. Wang ZY, Seto H, Fujioka S, Yoshida S, Chory J: BRII is a critical component of a plasma-membrane receptor for plant steroids. Nature 200I, 4I 0(6826):380-383.

43. Grant MR, Godiard L, Straube E, Ashfield T, Lewald J, Sattler A, Innes RW, Dangl JL: Structure of the Arabidopsis RPMI gene enabling dual specificity disease resistance. Science 1995, 269(5225):843-846.

44. Dixon MS, Jones DA, Keddie JS, Thomas CM, Harrison K, Jones JD: The tomato Cf-2 disease resistance locus comprises two functional genes encoding leucine-rich repeat proteins. Cell 1996, 84(3):45।-459.

45. Salmeron JM, Oldroyd GE, Rommens CM, Scofield SR, Kim HS, Lavelle DT, Dahlbeck D, Staskawicz Bj: Tomato Prf is a member of the leucine-rich repeat class of plant disease resistance genes and lies embedded within the Pto kinase gene cluster. Cell 1996, 86(I): 123-133

46. Parker JE, Coleman MJ, Szabo V, Frost LN, Schmidt R, van der Biezen EA, Moores T, Dean C, Daniels MJ, Jones JD: The Arabidopsis downy mildew resistance gene RPP5 shares similarity to the toll and interleukin-I receptors with $\mathbf{N}$ and L6. The Plant cell 1997, 9(6):879-894.

47. Milligan SB, Bodeau J, Yaghoobi J, Kaloshian I, Zabel P, Williamson VM: The root knot nematode resistance gene Mi from tomato is a member of the leucine zipper, nucleotide binding, leucinerich repeat family of plant genes. The Plant cell 1998, 10(8): $1307-1319$

48. Shen KA, Chin DB, Arroyo-Garcia R, Ochoa OE, Lavelle DO, Wroblewski T, Meyers BC, Michelmore RW: Dm3 is one member of a large constitutively expressed family of nucleotide binding site-leucine-rich repeat encoding genes. Mol Plant Microbe Interact 2002, I5(3):25I-26I.

49. Ayliffe MA, Frost DV, Finnegan EJ, Lawrence GJ, Anderson PA, Ellis JG: Analysis of alternative transcripts of the flax L6 rust resistance gene. Plant J 1999, I 7(3):287-292

50. Marathe R, Anandalakshmi R, Liu Y, Dinesh-Kumar SP: The tobacco mosaic virus resistance gene, N. Mol Plant Pathol 2002, 3(3):167-172

51. Anderson PA, Lawrence G], Morrish BC, Ayliffe MA, Finnegan EJ, Ellis JG: Inactivation of the flax rust resistance gene $M$ associated with loss of a repeated unit within the leucine-rich repeat coding region. The Plant cell I997, 9(4):64|-65I. 
52. Zhang XC, Gassmann W: RPS4-mediated disease resistance requires the combined presence of RPS4 transcripts with full-length and truncated open reading frames. The Plant cell 2003, I 5(10):2333-2342.

53. Borhan MH, Holub EB, Beynon JL, Rozwadowski K, Rimmer SR: The arabidopsis TIR-NB-LRR gene RACI confers resistance to Albugo candida (white rust) and is dependent on EDSI but not PAD4. Mol Plant Microbe Interact 2004, I 7(7):7| I-7| 9.

54. Schornack S, Ballvora A, Gurlebeck D, Peart J, Baulcombe D, Ganal $M$, Baker $B$, Bonas $U$, Lahaye $T$ : The tomato resistance protein Bs4 is a predicted non-nuclear TIR-NB-LRR protein that mediates defense responses to severely truncated derivatives of AvrBs4 and overexpressed AvrBs3. Plant J 2004 37(1):46-60.

55. Ferrier-Cana E, Macadre C, Sevignac M, David P, Langin T, Geffroy V: Distinct post-transcriptional modifications result into seven alternative transcripts of the CC-NBS-LRR gene JAItr of Phaseolus vulgaris. Theor Appl Genet 2005, I I 0(5):895-905.

56. Cai D, Kleine M, Kifle S, Harloff HJ, Sandal NN, Marcker KA, KleinLankhorst RM, Salentijn EM, Lange W, Stiekema WJ, Wyss U, Grundler FM, Jung C: Positional cloning of a gene for nematode resistance in sugar beet. Science 1997, 275(530I):832-834.

57. Yoshimura S, Yamanouchi U, Katayose Y, Toki S, Wang ZX, Kono I, Kurata N, Yano M, Iwata N, Sasaki T: Expression of Xa I, a bacterial blight-resistance gene in rice, is induced by bacterial inoculation. Proceedings of the National Academy of Sciences of the United States of America 1998, 95(4): 1663-1668.

58. Halterman DA, Wei F, Wise RP: Powdery mildew-induced Mla mRNAs are alternatively spliced and contain multiple upstream open reading frames. Plant physiology 2003, I 3 I (2):558-567.

59. Gu K, Yang B, Tian D, Wu L, Wang D, Sreekala C, Yang F, Chu Z, Wang GL, White FF, Yin Z: $R$ gene expression induced by a typeIII effector triggers disease resistance in rice. Nature 2005, 435(7045): I I22-II 25.

60. Collins N, Drake J, Ayliffe M, Sun Q, Ellis J, Hulbert S, Pryor T: Molecular characterization of the maize RpI-D rust resistance haplotype and its mutants. The Plant cell I999, I I (7): I365-1376.

61. Wang ZX, Yano M, Yamanouchi U, Iwamoto M, Monna L, Hayasaka $\mathrm{H}$, Katayose $\mathrm{Y}$, Sasaki T: The Pib gene for rice blast resistance belongs to the nucleotide binding and leucine-rich repeat class of plant disease resistance genes. Plant J 1999 19(I):55-64.

62. Wang ZX, Yamanouchi U, Katayose Y, Sasaki T, Yano M: Expression of the $\mathrm{Pib}$ rice-blast-resistance gene family is up-regulated by environmental conditions favouring infection and by chemical signals that trigger secondary plant defences. Plant molecular biology 200I, 47(5):653-66I.

63. Donson J, Fang Y, Espiritu-Santo G, Xing W, Salazar A, Miyamoto S, Armendarez V, Volkmuth W: Comprehensive gene expression analysis by transcript profiling. Plant molecular biology 2002 48(I-2):75-97.

64. Pollock JD: Gene expression profiling: methodological challenges, results, and prospects for addiction research. Chem Phys Lipids 2002, I 2 I (I-2):24I-256.

65. Adams MD, Kerlavage AR, Fleischmann RD, Fuldner RA, Bult CJ, Lee $\mathrm{NH}$, Kirkness EF, Weinstock KG, Gocayne JD, White O, Sutton G, Blake JA, Brandon RC, Chiu MW, Clayton RA, Cline RT, Cotton MD, Earle-Hughes J, Fine LD, FitzGerald LM, FitzHugh WM, Fritchman JL, Geoghagen NSM, Glodek A, Gnehm CL, Hanna MC, Hedblom E, Hinkle Jr. PS, Kelley JM, Klimek KM, et al.: Initial assessment of human gene diversity and expression patterns based upon 83 million nucleotides of cDNA sequence. Nature 1995, 377(6547 Suppl):3-I74.

66. Velculescu VE, Zhang L, Vogelstein B, Kinzler KW: Serial analysis of gene expression. Science 1995, 270(5235):484-487.

67. Brenner S, Johnson M, Bridgham J, Golda G, Lloyd DH, Johnson D, Luo S, McCurdy S, Foy M, Ewan M, Roth R, George D, Eletr S, Albrecht G, Vermaas E, Williams SR, Moon K, Burcham T, Pallas M DuBridge RB, Kirchner J, Fearon K, Mao J, Corcoran K: Gene expression analysis by massively parallel signature sequencing (MPSS) on microbead arrays. Nature biotechnology 2000, I 8(6):630-634.

68. Brenner S, Williams SR, Vermaas EH, Storck T, Moon K, McCollum C, Mao II, Luo S, Kirchner J], Eletr S, DuBridge RB, Burcham T, Albrecht G: In vitro cloning of complex mixtures of DNA on microbeads: physical separation of differentially expressed cDNAs. Proceedings of the National Academy of Sciences of the United States of America 2000, 97(4): $1665-1670$.

69. Rensink WA, Buell CR: Microarray expression profiling resources for plant genomics. Trends in plant science 2005, I0(12):603-609.

70. Galbraith DW: DNA microarray analyses in higher plants. Omics 2006, 10(4):455-473.

7I. Armstrong NJ, van de Wiel MA: Microarray data analysis: from hypotheses to conclusions using gene expression data. Cell Oncol 2004, 26(5-6):279-290.

72. Clarke JD, Zhu T: Microarray analysis of the transcriptome as a stepping stone towards understanding biological systems: practical considerations and perspectives. Plant J 2006, 45(4):630-650.

73. NibLrrs [http://niblrrs.ucdavis.edu]

74. Arabidopsis MPSS database [http://mpss.udel.edu/at/]

75. Meyers BC, Lee DK, Vu TH, Tej SS, Edberg SB, Matvienko M, Tindell LD: Arabidopsis MPSS. An online resource for quantitative expression analysis. Plant physiology 2004, 135(2):80I-8I3.

76. Meyers BC, Tej SS, Vu TH, Haudenschild CD, Agrawal V, Edberg SB, Ghazal H, Decola S: The use of MPSS for whole-genome transcriptional analysis in Arabidopsis. Genome research 2004 14(8): $164 \mid-1653$

77. Meyers BC, Vu TH, Tej SS, Ghazal H, Matvienko M, Agrawal V, Ning J, Haudenschild CD: Analysis of the transcriptional complexity of Arabidopsis thaliana by massively parallel signature sequencing. Nature biotechnology 2004, 22(8): I006-I0II.

78. Zipfel C, Robatzek S, Navarro L, Oakeley EJ, Jones JD, Felix G, Boller $\mathrm{T}$ : Bacterial disease resistance in Arabidopsis through flagellin perception. Nature 2004, 428(6984):764-767.

79. Kliebenstein DJ, West MA, van Leeuwen H, Kim K, Doerge RW, Michelmore RW, St Clair DA: Genomic survey of gene expression diversity in Arabidopsis thaliana. Genetics 2006, I72(2): $1179-1189$.

80. ELP [http://elp.ucdavis.edu/]

8I. Springer PS, McCombie WR, Sundaresan V, Martienssen RA: Gene trap tagging of PROLIFERA, an essential MCM2-3-5-like gene in Arabidopsis. Science 1995, 268(52 I 2):877-880.

82. Sundaresan V, Springer P, Volpe T, Haward S, Jones JD, Dean C, Ma $H$, Martienssen R: Patterns of gene action in plant development revealed by enhancer trap and gene trap transposable elements. Genes \& development 1995, 9(14): 1797-1810.

83. Martienssen RA: Functional genomics: probing plant gene function and expression with transposons. Proceedings of the National Academy of Sciences of the United States of America 1998, 95(5):202।-2026.

84. Parinov S, Sevugan M, Ye D, Yang WC, Kumaran M, Sundaresan V Analysis of flanking sequences from dissociation insertion lines: a database for reverse genetics in Arabidopsis. The Plant cell 1999, I I( I 2):2263-2270.

85. Arabidopsis Gene Trap Website at Cold Spring Harbor Lab [http://genetrap.cshl.org/]

86. Institute of Molecular Agrobiology lines [http://www.arabidop sis.org/abrc/ima.jsp]

87. Gu O, Ferrandiz C, Yanofsky MF, Martienssen R: The FRUITFULL MADS-box gene mediates cell differentiation during Arabidopsis fruit development. Development (Cambridge, England) 1998, I 25(8): I509-15 I7

88. Tsugeki R, Olson ML, Fedoroff NV: Transposon tagging and the study of root development in Arabidopsis. Gravit Space Biol Bull I998, I I (2):79-87.

89. TAIR [http://www.arabidopsis.org/]

90. Maleck K, Levine A, Eulgem T, Morgan A, Schmid J, Lawton KA, Dang JL, Dietrich RA: The transcriptome of Arabidopsis thaliana during systemic acquired resistance. Nature genetics 2000 , 26(4):403-4I0.

91. Tao Y, Xie Z, Chen W, Glazebrook J, Chang HS, Han B, Zhu T, Zou G, Katagiri F: Quantitative nature of Arabidopsis responses during compatible and incompatible interactions with the bacterial pathogen Pseudomonas syringae. The Plant cell 2003, I5(2):317-330.

92. Burch-Smith TM, Schiff M, Caplan JL, Tsao J, Czymmek K, DineshKumar SP: A Novel Role for the TIR Domain in Association with Pathogen-Derived Elicitors. PLoS Biol 2007, 5(3):e68. 
93. Peart IR, Mestre P, Lu R, Malcuit I, Baulcombe DC: NRGI, a CCNB-LRR protein, together with N, a TIR-NB-LRR protein, mediates resistance against tobacco mosaic virus. Curr Biol 2005, I 5( I 0):968-973.

94. Gabriels SH, Vossen JH, Ekengren SK, van Ooijen G, Abd-El-Haliem AM, van den Berg GC, Rainey DY, Martin GB, Takken FL, de Wit PJ, Joosten MH: An NB-LRR protein required for $H R$ signalling mediated by both extra- and intracellular resistance proteins. Plant J 2007, 50(I): I4-28.

95. Marathe R, Guan Z, Anandalakshmi R, Zhao H, Dinesh-Kumar SP. Study of Arabidopsis thaliana resistome in response to cucumber mosaic virus infection using whole genome microarray. Plant molecular biology 2004, 55(4):50I-520.

96. Arabidopsis splicing variations at TIGR [http://www.tigr.org/
[ tdb/e2kl/ath l/altsplicing/splicing variations.shtml]

97. Wang $B B$, Brendel $V$ : Genomewide comparative analysis of alternative splicing in plants. Proceedings of the National Academy of Sciences of the United States of America 2006, I 03( I 8):7175-7| 80.

98. Jordan T, Schornack S, Lahaye T: Alternative splicing of transcripts encoding Toll-like plant resistance proteins - what's the functional relevance to innate immunity? Trends in plant science 2002, 7(9):392-398.

99. Dinesh-Kumar SP, Baker B]: Alternatively spliced $\mathbf{N}$ resistance gene transcripts: their possible role in tobacco mosaic virus resistance. Proceedings of the National Academy of Sciences of the United States of America 2000, 97(4):|908-1913.

100. Gassmann W, Hinsch ME, Staskawicz BJ: The Arabidopsis RPS4 bacterial-resistance gene is a member of the TIR-NBS-LRR family of disease-resistance genes. Plant J 1999, 20(3):265-277.

I0I. Boyes DC, Nam J, Dangl JL: The Arabidopsis thaliana RPMI disease resistance gene product is a peripheral plasma membrane protein that is degraded coincident with the hypersensitive response. Proceedings of the National Academy of Sciences of the United States of America 1998, 95(26): I5849-I 5854.

102. Century KS, Lagman RA, Adkisson M, Morlan J, Tobias R, Schwartz K, Smith A, Love J, Ronald PC, Whalen MC: Short communication: developmental control of $\mathrm{Xa2} I$-mediated disease resistance in rice. Plant J 1999, 20(2):23 I-236.

103. van der Velden AW, Thomas AA: The role of the $\mathbf{5}^{\prime}$ untranslated region of an mRNA in translation regulation during development. The international journal of biochemistry \& cell biology 1999 , $3 I(I): 87-106$

104. Willis AE: Translational control of growth factor and protooncogene expression. The international journal of biochemistry \& cell biology 1999, 31 (I):73-86

105. Halterman D, Zhou F, Wei F, Wise RP, Schulze-Lefert P: The MLA6 coiled-coil, NBS-LRR protein confers AvrMla6-dependent resistance specificity to Blumeria graminis f. sp. hordei in barley and wheat. Plant J 200I, 25(3):335-348.

106. Altschul SF, Gish W, Miller W, Myers EW, Lipman DJ: Basic local alignment search tool. Journal of molecular biology 1990, 215(3):403-410.

107. Seki M, Narusaka M, Kamiya A, Ishida J, Satou M, Sakurai T, Nakajima M, Enju A, Akiyama K, Oono Y, Muramatsu M, Hayashizaki Y, Kawai J, Carninci P, Itoh M, Ishii Y, Arakawa T, Shibata K, Shinagawa A, Shinozaki K: Functional annotation of a full-length Arabidopsis cDNA collection. Science 2002, 296(5565): | $4|-| 45$.

108. TAIR BLAST [http://www.arabidopsis.org/Blast/]

109. Pearson WR, Lipman DJ: Improved tools for biological sequence comparison. Proceedings of the National Academy of Sciences of the United States of America 1988, 85(8):2444-2448.

1 10. Affymetrix [http://www.affymetrix.com]

III. Raw array data for flagellin experiment [http://www.ebi.ac.uk/ microarray-as/aer/dataselection?expid $=295433876$

II2. ELP finder [http://elp.ucdavis.edu/ parental survey ELP finder.htm]

1 13. Klimyuk VI, Carroll B], Thomas CM, Jones JD: Alkali treatment for rapid preparation of plant material for reliable PCR analysis. Plant J 1993, 3(3):493-494.

114. Jefferson RA, Kavanagh TA, Bevan MW: GUS fusions: beta-glucuronidase as a sensitive and versatile gene fusion marker in higher plants. The EMBO journal 1987, 6(13):390I-3907.

II5. Toriyama K, Thorsness MK, Nasrallah JB, Nasrallah ME: A Brassica $S$ locus gene promoter directs sporophytic expression in the anther tapetum of transgenic Arabidopsis. Developmental biology I99I, I43(2):427-43I.
116. Bradford MM: A rapid and sensitive method for the quantitation of microgram quantities of protein utilizing the principle of protein-dye binding. Analytical biochemistry 1976, 72:248-254.

II7. Tamaki S, Dahlbeck D, Staskawicz B, Keen NT: Characterization and expression of two avirulence genes cloned from Pseudomonas syringae pv. glycinea. Journal of bacteriology 1988 , I 70(10):4846-4854.

I I8. Debener T, Lehnackers H, Arnold M, Dangl JL: Identification and Molecular Mapping of a Single Arabidopsis-Thaliana Locus Determining Resistance to a Phytopathogenic Pseudomonas-Syringae Isolate. Plant J I 99|, I (3):289-302.

1 19. Century KS, Holub EB, Staskawicz BJ: NDRI, a locus of Arabidopsis thaliana that is required for disease resistance to both a bacterial and a fungal pathogen. Proceedings of the National Academy of Sciences of the United States of America 1995, 92(14):6597-660I.

120. Parker JE, Holub EB, Frost LN, Falk A, Gunn ND, Daniels MJ: Characterization of eds I, a mutation in Arabidopsis suppressing resistance to Peronospora parasitica specified by several different RPP genes. The Plant cell I 996, 8(I I):2033-2046.

12I. Bent AF, Kunkel BN, Dahlbeck D, Brown KL, Schmidt R, Giraudat J, Leung J, Staskawicz BJ: RPS2 of Arabidopsis thaliana: a leucinerich repeat class of plant disease resistance genes. Science 1994, 265(5 1 80): 1856-1860.

122. Mindrinos M, Katagiri F, Yu GL, Ausubel FM: The A. thaliana disease resistance gene RPS2 encodes a protein containing a nucleotide-binding site and leucine-rich repeats. Cell 1994, 78(6): $1089-1099$

123. Innes RW, Bent AF, Kunkel BN, Bisgrove SR, Staskawicz BJ: Molecular analysis of avirulence gene avrRpt2 and identification of a putative regulatory sequence common to all known Pseudomonas syringae avirulence genes. Journal of bacteriology 1993, I 75( (15):4859-4869.

124. Whalen MC, Innes RW, Bent AF, Staskawicz BJ: Identification of Pseudomonas syringae pathogens of Arabidopsis and a bacterial locus determining avirulence on both Arabidopsis and soybean. The Plant cell I99I, 3(I):49-59.

125. Hinsch M, Staskawicz B: Identification of a new Arabidopsis disease resistance locus, RPs4, and cloning of the corresponding avirulence gene, avrRps4, from Pseudomonas syringae pv. pisi. Mol Plant Microbe Interact 1996, 9( I):55-6I.

126. Aarts N, Metz M, Holub E, Staskawicz B], Daniels MJ, Parker JE: Different requirements for EDSI and NDRI by disease resistance genes define at least two $R$ gene-mediated signaling pathways in Arabidopsis. Proceedings of the National Academy of Sciences of the United States of America 1998, 95(I7): 10306-103II

127. Jenner C, Hitchin E, Mansfield J, Walters K, Betteridge P, Teverson D, Taylor J: Gene-for-gene interactions between Pseudomonas syringae pv. phaseolicola and Phaseolus. Mol Plant Microbe Interact 1991, 4(6):553-562.

128. Simonich MT, Innes RW: A disease resistance gene in Arabidopsis with specificity for the avrPph3 gene of Pseudomonas syringae pv. phaseolicola. Mol Plant Microbe Interact 1995, 8(4):637-640.

129. Rehmany AP, Gordon A, Rose LE, Allen RL, Armstrong MR, Whisson SC, Kamoun S, Tyler BM, Birch PR, Beynon JL: Differential recognition of highly divergent downy mildew avirulence gene alleles by RPPI resistance genes from two Arabidopsis lines. The Plant cell 2005, I7(6): 1839-1850.

130. van der Biezen EA, Freddie CT, Kahn K, Parker JE, Jones JD: Arabidopsis RPP4 is a member of the RPP5 multigene family of TIR-NB-LRR genes and confers downy mildew resistance through multiple signalling components. Plant J 2002, 29(4):439-45।.

131. McDowell JM, Cuzick A, Can C, Beynon J, Dangl JL, Holub EB: Downy mildew (Peronospora parasitica) resistance genes in Arabidopsis vary in functional requirements for NDRI, EDSI, NPRI and salicylic acid accumulation. Plant J 2000, 22(6):523-529.

132. Cooley MB, Pathirana S, Wu HJ, Kachroo P, Klessig DF: Members of the Arabidopsis HRT/RPP8 family of resistance genes confer resistance to both viral and oomycete pathogens. The Plant cell 2000, I 2(5):663-676.

133. Takahashi H, Miller J, Nozaki Y, Takeda M, Shah J, Hase S, Ikegami M, Ehara Y, Dinesh-Kumar SP: RCYI, an Arabidopsis thaliana 
RPP8/HRT family resistance gene, conferring resistance to cucumber mosaic virus requires salicylic acid, ethylene and a novel signal transduction mechanism. Plant J 2002, 32(5):655-667.

134. Bittner-Eddy PD, Crute IR, Holub EB, Beynon JL: RPP I 3 is a simple locus in Arabidopsis thaliana for alleles that specify downy mildew resistance to different avirulence determinants in Peronospora parasitica. Plant J 2000, 2I(2): 177-188.

135. Bittner-Eddy PD, Beynon JL: The Arabidopsis downy mildew resistance gene, RPPI3-Nd, functions independently of NDRI and EDSI and does not require the accumulation of salicylic acid. Mol Plant Microbe Interact 200I, I4(3):4I6-42I.

136. Allen RL, Bittner-Eddy PD, Grenville-Briggs LJ, Meitz JC, Rehmany AP, Rose LE, Beynon JL: Host-parasite coevolutionary conflict between Arabidopsis and downy mildew. Science 2004, 306(5703): 1957-1960.

137. Deslandes L, Olivier J, Theulieres F, Hirsch J, Feng DX, Bittner-Eddy $\mathrm{P}$, Beynon J, Marco Y: Resistance to Ralstonia solanacearum in Arabidopsis thaliana is conferred by the recessive RRSI-R gene, a member of a novel family of resistance genes. Proceedings of the National Academy of Sciences of the United States of America 2002, 99(4):2404-2409.

138. Deslandes L, Olivier J, Peeters N, Feng DX, Khounlotham M, Boucher C, Somssich I, Genin S, Marco Y: Physical interaction between RRSI-R, a protein conferring resistance to bacterial wilt, and PopP2, a type III effector targeted to the plant nucleus. Proceedings of the National Academy of Sciences of the United States of America 2003, I 00(I 3):8024-8029.

139. Sinapidou E, Williams K, Nott L, Bahkt S, Tor M, Crute I, Bittner-Eddy P, Beynon J: Two TIR:NB:LRR genes are required to specify resistance to Peronospora parasitica isolate Cala2 in Arabidopsis. Plant J 2004, 38(6):898-909.

140. Grant JJ, Chini A, Basu D, Loake GJ: Targeted activation tagging of the Arabidopsis NBS-LRR gene, ADR I, conveys resistance to virulent pathogens. Mol Plant Microbe Interact 2003, 16(8):669-680.

14I. Staal J, Kaliff M, Bohman S, Dixelius C: Transgressive segregation reveals two Arabidopsis TIR-NB-LRR resistance genes effective against Leptosphaeria maculans, causal agent of blackleg disease. Plant J 2006, 46(2):218-230.

Publish with Bio Med Central and every scientist can read your work free of charge

"BioMed Central will be the most significant development for disseminating the results of biomedical research in our lifetime. "

Sir Paul Nurse, Cancer Research UK

Your research papers will be:

- available free of charge to the entire biomedical community

- peer reviewed and published immediately upon acceptance

- cited in PubMed and archived on PubMed Central

- yours - you keep the copyright

Submit your manuscript here:

http://www.biomedcentral.com/info/publishing_adv.asp
BiolMedcentral 